\title{
The Ideology of Domination: Barriers to Client Autonomy in Legal Ethics Scholarship
}

\author{
Camille A. Gear
}

It might be said that anyone whose conscience is so tender that he cannot fulfill the prescribed obligations of a[n attorney] . . . should not undertake those obligations. He should not allow his moral scruples to operate as a trap for those who are told by the law that they may expect something more.

- Charles Fried

Ethics scholars know that when attorneys use their moral concerns to guide the representation of clients, attorneys can seriously undermine clients' autonomy. Scholars' concerns, however, are mitigated by their belief that lawyers must prevent clients from pursuing immoral goals. As a result, ethics scholarship contains two contrary directives. Lawyers are told that they must work to facilitate client autonomy ${ }^{2}$ and that they must use their power to prevent clients from pursuing immoral goals. ${ }^{3}$ These contrary assumptions create tension in the ethics literature: Lawyers are unsure where their power ends and where client autonomy begins. Ethics treatises resolve this tension by

1. Charles Fried, The Lawyer as Friend: The Moral Foundarions of the Lawyer Client Relation. 85 YALE L.J. 1060, 1065 (1976).

2. See, e.g., Monroe H. Freedman, Arguing the Law in an Adversany System, 16 GA. L. REV. 833. 835 (1982) (maintaining that the Model Rules of Professional Conduct requires altomeys to engage in zealous advocacy and therefore to help clients act autonomously under the law); Fried, supra note 1. at 1073 (arguing that the Constitution requires that we allow clients to exercise their autonomy under the law): Geoffrey C. Hazard, Jr., The Future of Legal Ethics, 100 Y ALE L.J. 1239 (1991) (arguing that the lawyer's historic role was to advance client autonomy); see also Drucilla Comell. Tosvard a Modem Postmodem Reconstruction of Ethics, 133 U. PA. L. REv. 291 (1985) (using philosophy to explain the importance of personal autonomy).

3. See, e.g., David B. Wilkins, Two Paths to the Mountaintop? The Role of Legal Educaston in Shaping the Values of Black Corporate Lawyers, 45 STAN. L. REV. 1981, 2022 (1993) (argung that lawyers have an obligation to engage in an independent determination of whether a client's goals are moral); Fred C. Zacharias, Reconciling Professionalism and Client Interests, 36 WM. \& MARY L. REV 1303, 1321 (1995) (same). 
instructing the attorney to limit a client's autonomy when the client's morality is alien to the attorney's chosen moral code. This general rule creates predictable consequences. The three prevailing ethics models-the lawyer-asstatesman, ${ }^{4}$ the lawyer-as-friend, ${ }^{5}$ and the lawyer-as-hired-gun ${ }^{6}$-encourage attorneys to subordinate their clients' interests and allow attorneys to use their moral frameworks in their representation of clients. ${ }^{7}$

I first noted the inconsistency in the traditional ethics models' underlying premises when I used the models to inform my representation of Arna Scott, a client in the Advocacy for Parents and Children Clinic at the Yale Law School. ${ }^{8}$ Ms. Scott is a thirty-five-year-old black woman who is HIV-positive, homeless, a substance abuser, and a domestic violence survivor. According to her file, Ms. Scott needed legal assistance in getting custody of her son Hayden, a three-year-old HIV-positive child. The State of Connecticut had taken custody of Hayden because Ms. Scott had failed to comply with her Department of Children and Families (DCF) treatment plan. ${ }^{9}$ Specifically, Ms. Scott had missed several of Hayden's medical appointments, had not found stable housing, and had not finished a substance abuse treatment program.

After my first meeting with Ms. Scott, my moral sensibilities rumbled, a cacophony of incoherent concerns. ${ }^{10}$ Ms. Scott seemed to be in violation of

4. The term "lawyer-as-statesman" as used in this discussion primarily refers to William Simon's ethical discretion model. See William H. Simon, Ethical Discretion in Lawyering, 101 HARV. L. REv. 1083 (1988). Under this model, the lawyer only pursues a client's goals if she advances the legal system's view of justice. The model is based secondarily on Anthony Kronman's lawyer-statesman ideal, which embodics a softer version of ethical discretion. See ANTHONY KRONMAN, THE LOST LAWYER: THE FAILING IDEALS OF THE LEGAL PROFESSION 144-45 (1993). The lawyer-statesman attomey privileges his clients' interests but reserves the option to refuse to help the client pursue goals that conflict with the legal system's vicw of justice. Kronman notes the inherent problems with suggesting that the lawyer intervene in this manner, but argues that "a courageous lawyer is prepared to take risks for what he or she believes is right-to risk anger, contempt and a lower income-for the sake of the law's own good." Id. at 145.

5. The lawyer-as-friend pursues only causes that advance the ideals of her moral code. See Fried, supra note 1 , at 1083-84. Fried argues that the lawyer may not impor her entire moral code into the representation, but he leaves it to the individual attomey to identify which of her moral values to use in the representation.

6. The lawyer-as-hired-gun advances a client's cause if her representation will allow the client to exercise her rights freely, in the way the Constitution intended. See Freedman, supra note 2, at 837.

7. See, e.g., Kronman, supra note 4; Monroe H. Freedman, The Lawyer's Moral Obligation of Justification, 74 TEX. L. REV. 111 (1995); David Luban, The Lysistrian Prerogative: A Response to Stephen Pepper, 1987 AM. B. FOUND. RES. J. 637.

8. Although my clinic supervisor gave me permission to use this client's story, I am still troubled by my decision to use her case to unravel my moral concerns. My hope is that her story will help attomeys learn how to enable their clients to claim their right to autonomy. In order to mask the identity of this client in the sketch that follows, the names of all involved parties have been changed. The sketch is a compositc based on several meetings I had with my client over a six-month period.

9. For a description of another state's process for developing a parent treatment plan, see Marcia Sprague \& Mark Hardin, Coordination of Juvenile and Criminal Court Child Abuse and Neglect Proceedings, 25 U. LOUISVILLE J. FAM. L. 239, 242 (1996-1997).

10. Several of the texts that describe the traditional ethics models are abstract theoretical discussions; this Note, in contrast, instrumentalizes principles in these discussions. Scholars disagree about whether philosophy is the best means of explaining the nature of legal ethics. Compare Roger C. Cramton \& Susan P. Koniak, Rule, Story, and Commitment in the Teaching of Legal Ethics, 38 WM. \& MARY L. REV. 145, 160-61 (1996) (arguing that philosophical ethics discussions usually are not well suited to addressing concrete lawyer problems), and Paul R. Tremblay, Practiced Moral Activism, 8 ST. THOMAS L. REv. 9. 
her treatment plan. She appeared to be very ill and physically exhausted. She also acted erratically, behavior that I knew in the past had triggered her DCF worker to suspect that she was using drugs. "Ms. Scott's words confirmed my worries. She explained that she had not contacted the clinic for six months because she had been in and out of the hospital recovering from various illnesses and from Hayden's father's assaults. ${ }^{12}$ Ms. Scott had not found permanent housing and had no permanent address or phone number. I informed Ms. Scott that Hayden's foster mother, a nurse who cared for HIV-positive children, wanted to adopt him. Ms. Scott immediately rejected this idea; she passionately wanted to be reunited with her son. Ms. Scott seemed surprised when I mentioned that, according to DCF records, she had not visited Hayden in the past three months. ${ }^{13}$

After our meeting, I asked myself whether an ethical attorney would help Ms. Scott pursue her wishes. ${ }^{14}$ My instincts suggested that I should focus on facilitating Ms. Scott's autonomy. I had joined the clinic because I was committed to helping poor people use the law to talk about the injustices in their lives. I knew that there were substantial obstacles to achieving my goal. The lawyer's superior knowledge of the law and her facility with legal language allow her to flout a client's wishes surreptitiously when she dislikes a client's goals. I also knew trust would be a problem. My perception of my client would be filtered through my own preconceptions and biases; sensing this, the client might not be truthful about her interests. ${ }^{\text {Is I }}$ recognized that my knowledge of the client would always be partial and limited. Still, I believed there must be a way to free the client to articulate and act on her desires.

Since my own concerns generated only doubt, I turned to the three prevailing ethics models ${ }^{16}$ to determine whether and how I should represent

10-14 (1995) (same), with KRONMAN, supra note 4, at 6 (arguing that philosophy can be helpful in discussions of lawyer ethics), and Fried, supra note I, at 1061 (same).

11. Ms. Scott's DCF worker often accused Ms. Scoll of drug use without any hard proof.

12. Ms. Scott's long absences may have resulted from mental illness. Cf. John Pelnla, Eshics. Money and the Problem of Managed Behavioral Health Care, 40 ST. LouIS U. L.J. 359, 394-95 (1992) (explauning that persons who are mentally ill and abuse substances periodically disappear and exhibul low (rust).

13. Subsequently, I learned that the DCF records were inaccurate: Ms. Scott had visited her son twice during the three-month period and had shown up at DCF offices on unscheduled days.

14. The Model Rules of Professional Conduct provide some guidance on ethical conduet. An attomey. however, may exercise additional discretion to control a client when it is approprate. See MODEL RULES OF PROFESSIONAL CONDUCT Rule $1.3 \mathrm{cmt}$. I (1995) ("[A] lawyer is not bound to press for every advantage that might be realized for a client.").

15. Cf. Austin Sarat \& William L.F. Felstiner, Law and Social Relations: Vocabularies of Motne in Lawyer/Client Interaction, in THE LAW AND SOCIETY READER 403. 405 (Richard Abel ed. 1995) (arguing that clients may speak in a different language of motive than the attoney in order to "resist the exercise of professional power").

16. See supra notes 4-6 and accompanying text; see also Froedman, supra note 7. al 114 (assigning professional ethics models different names): Jack L. Sammons, Rank Strangers to Me: Shaffer and Cochran's Friendship Model of Moral Counseling in the Low Office. $18 \mathrm{U}$. ARK. LTTLE ROCK LJ. I (1995) (same). 
Ms. Scott. The models provided answers, but they all cast Ms. Scott in the role of moral suspect. The lawyer-as-statesman model required me to assess whether Ms. Scott's case represented the cause of justice, as proscribed by the law. ${ }^{17}$ If not, I could deny Ms. Scott representation. The lawyer-as-friend model directed me to determine whether Ms. Scott's moral views were consonant with my own; if not, I could decline to represent her. The classical lawyer-as-hired-gun model directed me to refrain from morally judging Ms. Scott. To ensure that I did not, I could never engage in moral dialogue with her. If Ms. Scott proved to be so morally abhorrent that I ended up judging her, my moral concerns would control and I could drop her case. ${ }^{18}$

Although the various ethics models offered me clear direction, I was troubled that they all forced me into a conflict with my client. ${ }^{19}$ The models required that I identify what the bounds of morality were and that I use my conclusions to determine whether my client should be allowed to act autonomously. In the end, if my client could not articulate a moral vision with which I was familiar, the ethics models allowed me to deny her representation. I longed for an ethics paradigm that would allow me to help the client explain and expand her own independently constituted moral perspective. ${ }^{20}$ This approach seemed more consistent with the philosophical account of autonomy with which I was familiar: True autonomy means giving a person the opportunity to engage in independent moral judgment. ${ }^{21}$

This Note attacks the assumption in the ethics literature that the attorneyclient relationship must be a battle of moral visions. It challenges the idea that the attorney has a right to act as the moral decisionmaker in a client's case. Part I defines the key concepts of autonomy, ideology, and hegemony. Part I then identifies the "ideology of domination"-four constructs in the ethics literature that frame the attorney's perception so that she is predisposed to see conflict between her and her client's goals and predisposed to prevent the client from acting on the client's perceived alien morality. Part I argues that

17. See KRONMAN, supra note 4, at 15 (describing the lawyer-statesman model); Simon, supra note 4, at 1090 (describing the ethical discretion model); see also infra Section II.A (presenting the lawyer-asstatesman model).

18. This is the classical definition of the hired-gun model. The contemporary version, as modified by Monroe Freedman, is discussed later in more detail. See infra Section II.C. This contemporary version allows the attomey to choose a client based on the attomey's moral inclinations and allows the attorney to sever her relationship with her client if she determines that the client is immoral.

19. Cf. Charles J. Ogletree, Jr., Beyond Justifications: Seeking Motivations To Susfain Public Defenders, 106 HARV. L. REV. 1239, 1239 (1993) (arguing that lawyers need identity-sustaining justifications for why they have chosen to be lawyers and why they make work-related decisions).

20. Cf. Gerald P. Lopez, Reconceiving Civil Rights Practice: Seven Weeks in the Life of a Rebellious Collaboration, 77 GEO. L.J. 1603, 1613 (1989) (arguing that the practice of law is enriched by the perspectives of poor and disempowered persons).

21. Ethics scholars have rejected the idea that clients are "infinitely ... more valuable than any government . . . and that rules of legal ethics should be derived from th[is] premise." Monroe H. Freedman, The Professional Responsibility of the Law Professor: Three Neglected Questions, 39 VAND. L. RBV. 275, 275-76 (1986) (arguing that this kind of Christianity-based lawyer ethics has not taken persuasive hold in the community of ethics scholars). 
the ideology of domination has conditioned both traditional and oppositional scholars to devalue client autonomy. 22 Part II of the Note surveys the traditional ethics models to illustrate how the ideology-of-domination constructs focus attorneys' attention on attorney-client conflict and encourage attorneys to limit client autonomy. Part III shows how the ideology of domination has limited oppositional scholars' ability to create new ethics models that allow clients to act autonomously. ${ }^{23}$ Part IV outlines ways in which scholars can transcend the ideology-of-domination constructs, describing what I call the ethical mirror model. Part IV demonstrates that once we shift our ideological approach, we can reconfigure the attorney-client relationship in a way that facilitates clients' autonomous moral judgment.

\section{DEFINITIONS: AUtONOMY, IDEOLOGY, AND HEGEMONY}

\section{A. Autonomy}

Ethics scholars have numerous grounds for privileging client autonomy in the attorney-client relationship. Some argue that the lawyer was originally constituted to be an agent who allowed the client to function as an autonomous legal actor. ${ }^{24}$ Others insist that the Constitution requires attomeys to facilitate client autonomy. They argue that, logically, the constitutional provisions that secure a person rights would have little meaning if the person did not have a professional's assistance in exercising her rights. ${ }^{25}$ Additionally, ethics scholars argue that the adversary system was constituted to be an arena where competing interests clash. The system cannot function effectively, they argue, when clients are forced to rely on professionals who refuse to create legal

22. Oppositional scholars are scholars from Critucal Legal Studies (CLS). Cnucal Race Theory (CRT). and Feminist Legal Studies. See Eleanor Marie Brown. Note. The Tower of Babel: Bridging the Divide Between Critical Race Theony and "Mainstream" Civl Rights Scholarship. I0S YALE LJ. S13. 516 (1995) (describing the same group of scholars as "outsider" scholars). Since oppositional scholars have adopted the ideology of domination, they assume that there is a moral conflict between the attomey and the client. See, e.g., Richard Delgado, Rodrigo's Eleventh Chronicle: Empathy and False Empathy. 84 CAL L. REv. 61, 70-72 (1996) (arguing that true empathy will end attomey-client conflict): Peter Margulies. The Mother with Poor Judgment and Other Tales of the Unexpected: A Civil Republican View of Difference and Clinical Legal Education, 88 Nw. U. L. REV. 695 (1994) (arguing that better attention to conficting messages in clients' stories will end attomey-client conflict); Ogletree, supra note 19, at 1271.75 (arguing that immersion in the client's experience will end attomey-client conflict).

23. Oppositional scholars are surprised to find that their "day to day habits," thear "ways of secing. hearing, and responding to . . . clients, all too often have the ironic-indeed perverse-effect of repressing the capacities and aspirations of the very people and communitues [they] seek to help." Lucie B. White. Paradox, PieceWork, and Patience, 43 Hastings L.J. 853. 853 (1992).

24. See, e.g. Monroe H. Freedman, Professionalism in the American Adversan System, 41 EwORY LJ. 467, 467 (1992); Anthony T. Kronman. The Faul in Legal Eshics, 100 Dicx. L. REV. 489, 494 (1996) (arguing that one of the oldest justifications for client autonomy comes from the phslosophical doctrine of contractarianism).

25. See, e.g., Freedman, supra note 24 , at 470 . Scholars also point to the constitutional guarantees providing for the assistance of counsel in certain cases as textual proof that the founders intended that persons would be given a lawyer's help when seeking legal relief. See. e.g., id. 
claims that give unadulterated expression to clients' views. ${ }^{26}$ Lastly, ethics scholars note that the Model Code of Professional Responsibility directs lawyers to engage in zealous advocacy, ${ }^{27}$ suggesting that lawyers aggressively assist their clients in pursuing their clients' independently selected goals. ${ }^{28}$

Despite the numerous reasons for valuing client autonomy, most ethics scholars have begun to argue that client autonomy can be subordinated in favor of other issues, such as social justice, ${ }^{29}$ lawyers' responsibilities to third parties, ${ }^{30}$ and lawyers' interests in their own autonomy. ${ }^{31}$ Additionally, scholars argue that because the prevailing ethics models do not successfully facilitate client autonomy, we must consider whether client autonomy is an unrealistic value. ${ }^{32}$ Scholars who have increased their focus on values that undermine client autonomy fail to resolve two important issues. First, since we have constitutional, historical, and philosophical bases for affirming client autonomy, we should be slow to abandon the ideal, even if it is hard to achieve. Second, these new species of anti-autonomy concerns allow lawyers to mask their aggressive desires to control clients who make them uncomfortable, by arguing that their conduct is justified by competing social or philosophical concerns. Indeed, a lawyer invokes these competing concerns only when she cannot identify with the client's desires. The growing number and variety of justifications for limiting client autonomy suggest that ethics scholars see the attorney-client relationship as a battle of wills and that scholars know that a lawyer's decision to circumscribe the client's right to engage in autonomous moral judgment is suspect and must be explained.

I will try to direct scholars back to a focus on client autonomy by offering a more nuanced definition of the value. Joseph Kupfer, a moral philosopher, offers a helpful two-part explanation of autonomy. Autonomy, he explains, includes (1) the right to deliberate about moral judgments, and (2) the right to

26. See, e.g., Fried, supra note 1, at 1073; Kronman, supra note 24 , at 495 (noting that some believe that the hired-gun or contractarian lawyer assumes that a clash of views will make the legal system accurately reflect society's interests).

27. See MOdel CODE OF PROFEsSIONAL RESPONSIBILITY DR 7-101 (1981).

28. See, e.g., Simon, supra note 4, at 1086 (arguing that the libertarian hired-gun model of advocacy that allows clients to act autonomously is suggested by the Model Rules).

29. See Tremblay, supra note 10, at 11-27 (cataloguing the major ethics scholars' arguments for rejecting lawyering approaches that are solely devoted to client autonomy).

30. Cf. Freedman, supra note 21 , at 275 (claiming that because law professors are isolated from client contact, they tend to privilege third parties' interests over the interests of clients).

31. Kronman explains that the attorney's special knowledge about the law qualifies her to act as an autonomous agent who weighs whether clients should be allowed to pursue their goals. See KRONMAN, supra note 4, at 122-23. Fried argues that the attomey's autonomy is what allows her to express her individuality. See Fried, supra note 1, at 1069.

32. See, e.g., William H. Simon, Lawyer Advice and Client Autonomy: Mrs. Jones's Case, 50 MD. L. REV. 213, 213 (1991) (arguing from a traditionalist's perspective that client autonomy is an unrealizable goal); see also Anthony V. Alfieri, Reconstructive Poverty Law Practice: Learning Lessons of Client Narrative, 100 YALE L.J. 2107, 2111 (1991) (arguing as a CLS scholar that scholars must contend with the fact that lawyer translation of client interests inevitably silences clients in some manner); White, supra note 23, at 853 (noting that oppositional scholars recognize that their lawyering styles compromise clients' autonomy). 
act on those judgments. ${ }^{33}$ According to Kupfer, these two rights cannot be separated, for autonomy in one sphere is meaningless without autonomy in the other. $^{34}$ Kupfer notes that the precondition for autonomous action is autonomous judgment, which involves "forming beliefs on the basis of evidence, reasoning from similar cases, and anticipating contingencies as well as estimating their likelihood." 35 Kupfer argues that these skills must be taught. The ideology of domination that I will describe encourages attomeys to deprive clients of the right to engage in autonomous moral judgment and therefore denies clients true autonomy. The ideology also encourages attorneys to deny clients the assistance they may need to develop their own moral decisionmaking skills.

\section{B. Ideology}

Ethics scholars subordinate the value of client autonomy in their work because they are locked in a limiting mode of ideological thought. ${ }^{36}$ Ideological thought naturalizes certain ways of seeing the world. ${ }^{37}$ It "disable[s]" the mind and offers a perspective so seductive that it prevents a person from even " "imagin[ing] that life could be different and better." 38 Ideology limits people's thoughts by limiting their language choices. ${ }^{39}$ The ideological language used to refer to relationships and objects shapes one's perception of the things to which the language refers. ${ }^{40}$ Scholars who use the same language, therefore, will tend to imagine social phenomena in similar ways.

Ideology powerfully shapes perception," allowing it to achieve a second, related goal: the production of attractive identities. Ideological identities shape people's perceptions of themselves and their needs by convincing them to use

33. See JOSEPH H. KUPFER, AUTONOMY AND SOCIAL INTERACTON 10-14 (1990).

34. See id. at 18 .

35. Id. at 10 .

36. Cf. TERRY EAGLETON, IDEOLOGY 15 (1991) (explaining how ideology limils perception): STUART Hall, Critical Dialogues in Cultural Studies 26 (David Morley \& Kuan-Hsing Chen eds., 1996) (explaining how ideology enables people to make sense of their environments and social relauonships).

37. See Milner S. Ball, The Politics of Law: A Progressive Crilique. 51 Geo. WaSh. L. Rev. 309. 311 (1983) (book review) (citing Robert W. Gordon, New Developments in Legal Theory, in THE POLmcs of LAw 286, 287 (David Kairys ed., 1982)); see also HaLL, supra note 36, at 26.

38. Ball, supra note 37, at 311 (quoting Gordon, supra note 37, al 287).

39. See HALL, supra note 36, at 26. This Note relies on Antonto Gramsei's definition of ideology. which is used in most CLS scholars' and cultural studies scholars' work. Gramsel's explanation of ideological functioning is superior to those of other scholars because he presumes that individuals have the power to resist ideological messages and that they choose among competing ideological regimes. See id.

40. See EAGLETON, supra note 36, at 15; HALL, supra note 36, at 26.

41. See JUDITH BUTLER, GENDER TROUBLE: FEMINISM AND THE SUBVERSION OF IDENTTTY at IX (1990) (explaining that identity categories are "the effects of institutions. practices [and) discourses"): ExGLETON, supra note 36 , at 1-2 (discussing ideology's role in creating subject positions and creating relationships between the subject and social institutions). 
the ideology's language to describe their interests. ${ }^{42}$ Ideology, however, does not wholly manufacture a person's interests. Rather,

ruling ideologies can actively shape the wants and desires of those subjected to them; but ... they ... also engage significantly with the wants and desires that people already have, catching up genuine hopes and needs, reinflecting them in the [ideology's] own peculiar idiom, and feeding them back to their subjects in ways which render these ideologies plausible and attractive. ${ }^{43}$

Stated simply, an ideological identity translates a person's amorphous needs into a set of cognizable desires and suggests practices that can be used to achieve these desires. ${ }^{44}$

Although different ideologies always compete in a society, some ideological constructs become hegemonic. ${ }^{45}$ Hegemonic ideas are ideological constructs that are so naturalized that they are reduced to natural impulses and common sense, even though these ideas are actually instilled by a process of cultural socialization. ${ }^{46}$ To prevent revolutionary action, persons whose social power is premised on a particular ideology attempt to make the ideology hegemonic. For when "elites can shape the consciousness of would be insurgents," the insurgents' critiques still employ hegemonic ideas, and in this way "sustain [prevailing] forms of inequality and domination."

\section{The Ideology of Domination Defined: The Four Constructs}

The preceding insights about ideology suggest that the ethics literature serves as an ideology that defines the scope and substance of lawyering. All the ethics models describe the attorney-client relationship similarly. For example, all suggest that the attorney is the correct person to dictate morality within the attorney-client relationship. Additionally, all suggest that it is proper for the attorney to express her moral and political predispositions in the selection of clients. Relatedly, all suggest that the attorney's clientele function

42. See EAGLETON, supra note 36 , at 14-15.

43. Id.

44. Cf. JUDITH BUTLER, Bodies That MATtER at $x$-xi (1993) (explaining that one can analyze ideologies for identity-performance practices other than practices used to enact gender identity).

45. See HALL, supra note 36 , at 30 (describing the Althusserian idea of how "ideology becomes internalized, how we come to speak spontaneously within the limits of categories of thought").

46. See id. at 27 (summarizing Gramsci's insights and describing how some ideology evolves into "language of practical thought which stabilizes a particular form of power and domination; or which reconcile and accommodate the mass of the people to [a] subordinate position").

47. James Gray Pope, Labor's Constitution of Freedom, 106 YALE L.J. 941 , 951 (1997). Pope, a CLS scholar, invites us to imagine a world dominated by hegemonic thought: "In this [world], A might exercise power over $B$ not only by excluding her grievances from the public agenda, but also by preventing her from recognizing them as remediable problems, or even by convincing her that she is not the kind of person who is capable of defining and acting on grievances." $1 d$. at 950 . 
as a reflection of the attorney's identity. Lastly, all allow the attorney to sever the attorney-client relationship when the attorney concludes that the client is an immoral or amoral actor. This phenomena of shared perception is one of the definitive signs that an ideology is at work. Under a Gramscian model of ideology, one knows that "ideology [has] become[] internalized ... [when persons] come to speak spontaneously within limited categories of thought."48 Ethics scholars' shared perceptions of clients are the inevitable result of their use of a common set of linguistic constructs to discuss the attorney-client relationship. The following discussion outlines the ideology of domination, a group of shared linguistic constructs, to show how the ideology unifies ethics scholars in a limited and autonomy-compromising view of clients.

The ideology of domination is made up of four constructs: (1) the assumption that the attorney experiences "a discretionary moment"; (2) the description of the "client as a threat" to the attorney's professional identity; (3) the description of the attorney as a "system protector"; and (4) "the call to ideological fidelity"-the assumption that the attorney must operate consistently under a single ethics model. Collectively, these constructs ensure that the attorney develops an aggressive posture in the representation, one conducive to moral judgment or prone to emotional distance. ${ }^{49}$ Because these constructs permeate the dominant ethics models, an attorney who wants to avoid dominating clients cannot find a principled theoretical approach to guide her representation. ${ }^{50}$ I will now describe the four ideology-of-domination constructs to make it easier to identify their use in each of the three prevailing ethics models.

The first construct, the discretionary moment, occurs when the attorney confronts the client's demands and decides whether her client's moral goals are reconcilable with her own moral code ${ }^{51}$ or the legal system's moral commands. ${ }^{52}$ The discretionary-moment construct precipitates attorney-client conflict because it naturalizes the idea that the attorney should think about and act on her own world view instead of focusing on her clients' articulated interests. ${ }^{53}$ The construct prevents the attorney from imagining an attorneyclient relationship that prohibits the attorney from factoring her chosen moral frame into her clients' decisions. In addition, the discretionary-moment construct encourages attorney paternalism because it makes the lawyer believe that her discretionary power to direct client ends makes her responsible for her

48. HALL, supra note 36 , at 30 .

49. See KRONMAN, supra note 4, at 97-98.

50. See López, supra note 20 , at 1607 (arguing that lawyers fightıng against the domunant approaches of lawyering resist practices "more through instinct than through self-conscious design").

51. See Fried, supra note 1, at 1065.

52. See KRONMAN, supra note 4 , at is.

53. See MODEl RULES OF PROFEsSional CONDUCT Rule 2.1 (1995) ("In representing a client, a lawyer ... may refer not only to law but to ... moral, economic, social and politucal factors ...."). 
clients' goals. ${ }^{54}$ The construct prevents the attorney from seeing herself as a translator who frames her client's legal interests. Instead, the lawyer is made to believe that she must actively shape her client's moral goals and deny the client representation if the client refuses to submit.

The discretionary moment is intimately linked to the second construct in the ethics literature: the perception of the client as a threat. The lawyer is encouraged to believe that in adopting the client's interests she puts her own moral identity at risk. ${ }^{55}$ The ethics literature focuses on scenarios in which clients have unattractive moral goals, thus inaccurately characterizing the attorney-client relationship as an inevitable moral tug of war. ${ }^{56}$ The client-asthreat construct also freezes the attorney's imagination, preventing her from seeing the lawyer-client relationship as a collaborative and client-directed endeavor. Lawyers who expect their clients to be threats will be hostile to clients' contrary moral views. ${ }^{57}$ They are unlikely to listen to clients' insights about the legal system or complaints about the attorneys' moral views. Instead, these attorneys' defensive postures make them react to their clients' moral visions by thinking of ways to reframe clients' goals.

The third construct, the lawyer as system protector, naturalizes the assumption that the attorney's function is to uphold the law. ${ }^{58}$ The construct requires the attorney to express faith in the legal system's assessment of justice. ${ }^{59}$ The system-protector construct ${ }^{60}$ makes attorneys less likely to believe that their clients have suffered injuries when their injuries cannot be

54. See, e.g., id. cmt. 2 ("It is proper for a lawyer to refer to relevant moral and ethical considerations in giving advice.").

55. See, e.g., KRONMAN, supra note 4, at 114 (arguing that lawyers fear that they are required to forfeit their consciences when they represent clients). CRT scholar David Wilkins also notes that the lawyer's moral identity is tied to client representation. He argues that the lawyer has a right to find moral satisfaction in her work and this right brings a responsibility for client goals. See Wilkins, supra notc 3 , at 1985. Note that, because Wilkins sees the lawyer's selection of clients and the lawyer's suggestion of client means and ends as part of the lawyer's identity, he also makes the lawyer responsible for her clients" resulting actions.

56. Scholars have noted that, in reality, lawyers tend to gravitate toward clients with interests similar to their own. See Wilkins, supra note 3, at 2022; Zacharias, supra note 3, at 1303.

57. Cf. Monroe H. Freedman, Legal Ethics and the Suffering Client, 36 CATH. U. L. REv. 331, 334-36 (1987) (noting that a lawyer is likely to be resistant to a client's efforts to pursue a moral course of action that the lawyer perceives as alien, and the lawyer is unlikely to change her own moral view).

58. See Kronman, supra note 4, at 138 (arguing that the lawyer's goal is to help a client while advancing the law's well-being); see also Fried, supra note 1, at 1081 (arguing that when the lawyer advocates for a client in ways that shape the law, the "lawyer's conduct ... travels outside the bounds of legal friendship and becomes political friendship, political agitation, or friendship tout court").

59. See Fried, supra note 1, at 1081 (noting that zealous advocacy does not require the belief that the legal system fails to protect clients' rights adequately).

60. The system-protector construct is relatively weak, and may not describe the lawyer's experience with perfect accuracy. For example, civil rights lawyers, public defenders, and corporate lawyers regularly flout the substantive law by stretching legal rules and procedural protections to help their clients. See William H. Simon, Should Lawyers Obey the Law?, 38 WM. \& MARY L. Rev. 217, 228-39 (1996) (cataloguing examples of heroic lawyers in literature, legal studies, and popular culture who do not adhere to the system-protector construct). 
resolved by the established law. ${ }^{61}$ Additionally, the construct makes attorneys less likely to value clients' pain when this pain is invisible under traditional legal and moral discourse. ${ }^{62}$

The fourth hegemonic construct in the ethics literature is the call to ideological fidelity. This construct makes each of the ethics models seem as though it is a hermetically sealed world view. The attorney is directed to filter all client information and to base all client decisions on her chosen ethics model, in order to protect the integrity of the attorney's personal moral code. The call to ideological fidelity is dangerous because it makes the attorney less attentive to information that challenges her chosen ethics model. ${ }^{63}$ Once an ideology is adopted, it is constitutive and constituting: A person tends to notice only information that confirms the ideology. ${ }^{\text {s }}$ The call to ideological fidelity also aggravates the attorney's aggressive relationship with her client. The ethics literature makes the attorney focus on faithfully enacting her chosen ethics model under the threat that if she deviates she will suffer an identity crisis. The lawyer therefore is hostile to the client's articulation of an alien ethics code because the client's ethics code both distracts the attorney from her personal identity project and poses a challenge to her world view. ${ }^{\text {s }}$

Judith Butler's identity-performance theory provides a theoretical basis for this claim. ${ }^{66}$ Butler explains that an individual's identity-maintenance

61. This construct has a disproportionate effect on margınalized communitues. Cf. David B. Wilkıns. Practical Wisdom for Pracricing Lawyers: Separating Ideals from Ideology in Legal Ethucs, 108 HARV L. REV. 458, $469-70$ (1994) (reviewing KRONMAN, supra note 4) (describing issues that suggest that marginalized communities need lawyers who are not system prolector).

62. Roger Cramton and Susan Koniak argue that the system-protector construct performs two functions: It minimizes lawyers' understanding of clients pain, and 11 prevents clients from secunng the means to change the law. Cramton and Koniak explain that because the system-protector lawyer

must proceed on the presumption that present conditions are not so temble, that currenily existing society is not so unjust, comupt or violent. [she] begin[s] with a blindness to the pann of those who have been or are now the victums of society's great wrongs [Therefore t]he pain of these [victims] cannot be so greal because sociely is not so bad. or so the [systemprotector] must believe.

Cramton \& Koniak, supra note 10, at 196. Cramton and Kontak's observation also shows that lawyers from marginalized communities are further marginalized by the ethics litersture. For example, one wonders how a Native American attomey could believe that the law promotes justuce, given the wild vacillation in the definition of Native Americans' rights over the past 100 years.

63. See Pope, supra note 47, al 950 (Citing RaYMoNd WILLAMMS, MarXISM ANd LTtERATLRE III (1977)).

64. See id.

65. Only recently have legal scholars started to look at how legally constituted ideologies construct people's identities. See, e.g., James Boyle, Is Subjectivin Possible? The Posimodern Subject in Legal Theory, 62 U. COLO. L. REv. 489. 504 (1991) (arguing that CLS has pasd insufficient altention to the concept of subject formation).

66. See BUTLER, supra note 44, at $x$-xi. Identty-performance theory can be used to analyze the ethics literature because ethics scholars argue that lawyers should soe professional idenitly as their promary identity and that lawyers should use the ethics literature to define therr identuty perspectives. See. e.g.. Geoffrey C. Hazard, Jr., Dimensions of Ethical Responsibiltn:: Relevant Others. 54 U. PITT L. REV. 965 (1993); see also Kenneth Anderson, A New Class of Lawyers: The Therapeutic as Rights Talk. 96 ColuM. L. REV. 1062, 1069 (1996) (review essay) ("II]ncreasingly, the law has become the only personal identuty for its practitioners, lawyers are increasingly unable to define themselves in terms other than thest occupational and professional ones."). Anderson show's that ethics literature, commencement addresses, and 
drive ${ }^{67}$ requires the individual to do the following: (1) distinguish herself from others; ${ }^{68}$ (2) search for paradigmatic examples of her chosen identity; ${ }^{69}$ (3) develop identity-affirming practices; $;^{70}$ and (4) engage in these practices compulsively. ${ }^{71}$ With Butler's insights, one notes that the ethics literature has the characteristics of an identity-maintenance medium. The literature is preoccupied with determining what distinguishes lawyers from other professionals. ${ }^{72}$ The discussions suggest that the professional ethics models are paradigmatic examples of lawyer identity and provide real-life examples of the personae. The literature distills the models into practices ${ }^{73}$ and encourages lawyers repetitively to engage in these practices. ${ }^{74}$ In addition, the literature requires the attorney to choose one professional ethics model as her ethics identity. ${ }^{75}$

When the ethics literature is examined as an identity-performance medium, the destructive potential of the call to ideological fidelity is revealed. Lawyers,

clinic classes suggest that professional identity is the lawyer's primary identity. Anderson also notes that because modern lawyers spend more time at work than lawyers did in the past, they have tended to express their personal and political commitments in their professional lives. See Anderson, supra, at 1069-72.

67. Butler's theory is easily extended to other areas of identity maintenance because it is based on a theory that addresses identity-formation practices generally. See, e.g., J.L. AUSTIN, HOW TO DO THINOS WITH WORDS (1962) (describing how identities are structured through language); JOHN R. SEARLE, SPEECH ACTS: AN ESSAY IN THE PHILOSOPHY OF LANGUAGE (1969) (elaborating on Austin's theory). Austin and Searle theorize about the linguistic distinctions between words' power to perform things and words' imprecise enactment of the speaker's intended performance. Butler has instrumentalized their ideas in her work. See BUTLER, supra note 44 , at $x$-xi.

68. See BUTLER, supra note 44, at ix-x; see also Jemy Frug, Decentralizing Decentralization, $60 \mathrm{U}$. CHI. L. REV. 253, 306-07 (1993) (describing Butler's performativity theory).

69. See BUTLER, supra note 44 , at $x$-xi. Butler's theory might be criticized for oversimplifying the process by which persons select gender-identity-affirming practices because it is difficult to locatc uncontested articulations of gender in modern social discourse. In contrast, models of professional identity are fairly static, and ethics treatments habitually refer to paradigmatic examples of professionalism. Therefore, Butler's performativity theory has great explanatory power in discussions of professional identity.

70. See id.

71. See id. Several legal scholars have discussed Butler's performativity analysis. See, e.g., Martha M. Ertman, Contractual Purgatory for Sexual Marginorities: Not Heaven, but Not Hell Either, 73 DENv. U. L. REV. 1107, 1166 (1996) (using a performativity model to analyze sexual orientation and gender identity); Katherine M. Franke, What's Wrong with Sexual Harassment?, 49 STAN. L. REV. 691, 771 (1997) (same). Scholars are also beginning to extend the model. See Judith Butler, Burning Acts: Injurious Speech, 3 U. CHI. ROUNDTABLE 199, 199-204 (1996) (using performativity to analyze hate speech); Frug, supra notc 68 , at 262-63 (using performativity to explain how municipalities are treated as legal subjects). Thus far, no scholar has used it to analyze lawyers' identity-maintenance strategies.

72. See, e.g., Fried, supra note 1, at 1063 (comparing a lawyer's duty of care to a doctor's duty of care); Hazard, supra note 66, at 965 (arguing that ethical standards used in other professions can be used to determine bases for lawyer ethics).

73. See KRONMAN, supra note 4, at 14-15 (describing practices that identify the lawyer-statesman); Gerald P. Lopez, An Aversion to Clients: Loving Humanity and Hating Human Beings, 31 HARV. C.R.-C.L. L. REV. 315, 322 (1996) (identifying practices that define a progressive lawyer).

74. Cf. KRONMAN, supra note 4, at 1-4 (arguing that deviation from the lawyer-statesman model has made lawyers lose their identity); Freedman, supra note 57, at 336 (arguing that there is no acceptable alternative to a model other than the contemporary hired-gun approach).

75. See, e.g., KRONMAN, supra note 4, at 7 (urging lawyers to restore the lawyer-statesman model); López, supra note 73, at 322 (drawing a more loosely defined, but exclusive model of progressive lawyering). 
preoccupied with their desire to enact their own identities, may view clients' articulation of contrary moral views to be interruptions of their own identity projects. Lawyers' identity-maintenance drives will be aggressive, for identity maintenance places special importance on forcing others to recognize one's chosen identity. ${ }^{76}$ Therefore, when a client challenges her attorney's ethical vision, the attorney may try to reshape the client's interests so that the client can assume her proper role in the attorney's identity-performance project. In this way, the call to ideological fidelity prevents attorneys from responding properly to the different needs of their various clients.

Collectively, the ideology-of-domination constructs encourage the attorney to control client autonomy. If the client is a threat, the attorney must contain the client's influence. If the attomey is a system protector, she must aggressively defend the legal system. The discretionary moment gives the attorney the opportunity to limit client autonomy; she determines whether she should deny the client her help and whether to reshape the client's goals. The call to ideological fidelity ensures that attorneys do not have disparate experiences that would inspire them to challenge each ethics model's ideological approach. In addition, it encourages the attorney to bring her aggressive identity-performance needs into the attorney-client relationship.

Admittedly, the term "client" describes a diverse group, ranging from poor, middle-class, and wealthy individuals to public interest organizations, the state, and corporations. While the ideology of domination affects all clients, regardless of their wealth and social power, poor clients may feel its effects most acutely because such clients are likely to present moral problems with which the lawyer is unfamiliar. Because lawyers are predominately middle class, and because their legal education socializes them to have an affinity with the middle class, ${ }^{77}$ they may feel alienated by poor clients' problems. In these moments of alienation, the lawyer is likely to turn to the ethics models for guidance. Since the ethics literature suppors the notion that the attorney is entitled and often obligated to use her moral code to control clients, poor clients are put in a situation in which they must convince their attorneys that their goals are consistent with their attorneys' chosen moral codes. If a client is unconvincing, she may be denied representation. ${ }^{78}$ Rather than advising the

76. See BUTLER, supra note 44, at 18-19. In the context of gender identuly. Butler notes that a person stops compulsively engaging in identity practices when she foels that she has marked her body so that she is socially recognized as a given gender. See id.

77. See KRONMAN, supra note 4, at 155.

78. Given the attomey's superior power, a poor client knows that resistance is futile. The altomey's specialized knowledge about the law allows the attomey 10 act so that the elient may be unaware that her interests are being thwarted. See MODEL RULES OF PROFESSIONAL CONDLCT Rule $1.3 \mathrm{cmt} .1$ (1995) ("“(A) lawyer is not bound to press for every advantage that might be realized for a client."): id. ("A lawyer has professional discretion in determining the means by which a matter should be pursued."). Even if she learns of her lawyer's betrayal, the client's lack of legal knowledge will make her ill-equipped to respond to tt. A poor client will often feel it is useless to change attomeys because she is aware that if she cannot convince her current attomey of her morality, her next attorney may not believe her etther. Finally, the 
attorney to use her power over poor clients judiciously, the traditional ethics literature encourages her to flex her strength whenever her moral sensibilities demand it.

The ideology of domination circumscribes wealthy individual clients and corporate clients in a more subtle manner. Such clients enjoy a range of effective resistance strategies, the most important being the power of exit. ${ }^{79}$ Indeed, these clients may choose their attorneys, and attorneys often feel as though their livelihood depends on these clients' goodwill.$^{80}$ The ideology-ofdomination scholarship constructs this phenomenon as a problem. In the event of lawyer-client conflict, the ethics literature advises lawyers working with relatively powerful clients to "be courageous," convince the client that the attorney is the right person to serve as arbiter of moral goals in the relationship. ${ }^{82}$ Clients with cultural and financial capital can often effectively control lawyers. Indeed, these clients usually have better facility with language than do poor clients and come from the same moral universe as the attorney. As a result, they are more successful in convincing attorneys that their goals are ethically sound.

\section{Overcoming Limiting Ideologies}

Increasingly, there are signs that the ideology of domination has become hegemonic. As previously explained, hegemonic ideas prevent scholars from conceiving of new approaches to problems. Indeed, oppositional ethics scholars have begun to argue that they cannot theorize models that avoid attorney antagonism. Oppositional scholars complaining of this problem employ the ideology-of-domination constructs in their work. Because these constructs frame and limit perception, scholars using this language inevitably cast the attorney-client relationship as an antagonistic one. As long as oppositional scholars use these constructs, they will be unable to construct radical new ways of seeing the attorney-client relationship.

Once we understand that the ethics literature functions as an ideology and that it encodes hegemonic principles, we can better identify the work that is before us. Although CLS scholars note that we can never fully escape

attomey has more power over the client because she enjoys almost limitless discretion to cnd the relationship on moral grounds. See id. Rule 1.16(b) (stating that a lawyer may withdraw when her client's objective is "repugnant or imprudent" or for "good cause").

79. See Fried, supra note 1, at 1065-66 (arguing that the client can wield the power of exit to show her dissatisfaction with her lawyer).

80. Kronman worries that clients will not hire lawyers who attempt to limit them from pursuing immoral ends. He calls for lawyers to be courageous and to reclaim their power. See KRONMAN, supra note 4, at 7 . Simon makes the same argument. See Simon, supra note 4, at 1129.

81. KRONMAN, supra note 4, at 145 .

82. See Sarat \& Felstiner, supra note 15, at 418 (arguing that lawyers handling personal matters often tell clients to be suspicious of their own judgment because they are too emotional to make rational decisions about legal strategy). 
ideology, they believe that we must "make maps of [ideological] value systems" and show how ideological beliefs "guide and limit perception." These maps can be used to "liberate thought" by elucidating the "false constraints of these belief systems: by showing the historical contingency of belief-structures, empirically disproving claims of necessity, and exposing the incoherence of various theories." ideology "lends to contingent, value-laden decisions an air of neutrality, inevitability, and rightness and ... allows decision makers to deny responsibility for the suffering their judgments create." ${ }^{\text {"ss }}$

In addition to pointing out the limits of existing ideologies, ideological maps allow one to create new ideologies that escape the old ideology's limiting framework. Social theorists Ernesto Laclau and Chantal Mouffe explain that we can use ideology maps as markers and form oppositional ideologies by testing our ideas against these maps to ensure they escape the debunked ideological framework. ${ }^{86}$ Part II will follow Laclau and Mouffe's recipe for revolutionary thought by drawing a map of the four ideological constructs that I have called collectively the ideology of domination, and by highlighting the problems that flow from the ideology's constructs. The ideology map will then be used in Part III to survey oppositional scholars' successes and failures in breaking free of the ideology. In Part IV, the map will be used to create an alternative position in opposition to the ideology of domination: the ethical mirror model.

\section{THE THREe MOdels DeFINED}

\section{A. The Lawyer-as-Statesman Model}

When Arna Scott asked me if I would take her case, I first assessed her cause under the lawyer-as-statesman ethics model, which requires an attorney to use her "practical wisdom" 87 or "discretionary judgment" 88 to determine whether the client's interests are consistent with the law and therefore worthy of representation. ${ }^{89}$ The lawyer-as-statesman model posits that the lawyer's

83. Ball, supra note 37 , at 312 (summarizıng Gordon, supra note 37, at 289).

84. Id.

85. Id. at 311 .

86. See ERnesto laclau \& Chantal molife. Hegenony \& Socialist Strategy. Towards RADICAL DEMOCRATIC POLmCS 67. 186 (1985): see also Whutc, supra note 23. at 856-59 (descnbing strategies for avoiding ideology-based descriptions of clients); $c f$. HALL. supra note 36. al 26 (arguing that "[w]e need to understand [the] role [ideas play] in a paricular social formation, so as 10 infom the struggle to change society").

87. KRONMAN, supra note 4 , at 2-4, 14-17.

88. Simon, supra note 4. at 1086; see also Willıam H. Simon. The Eihucs of Criminal Defense. 91 MiCH. L. REV. 1703, 1703 (1993) (arguing that crimunal defense lawyers should use an ethical discretion approach to lawyering).

89. See Simon, supra note 4 , at 1083. 
experiences with the legal system ${ }^{90}$ or her special training ${ }^{91}$ give her the unique ability to sort through "competing legal ideals" 92 and, therefore, prepare her to advance the cause "that seem[s] most likely to promote justice." only legal strategies that are consistent with the legal system's values. ${ }^{94}$ If the client's interests become inconsistent with the law's purposes, the lawyer teaches the client that the law enacts the correct moral code. ${ }^{95}$

The lawyer-as-statesman model suggested that I should decline to represent Ms. Scott. Ms. Scott's interests were not consistent with the fundamental values behind the legal rules. Because Ms. Scott had not complied with her treatment plan and because she still represented a danger to Hayden, I would not be pursuing the cause of justice by pushing for their reunion. Additionally, because there were allegedly more deserving clients in the clinic who could benefit from my services-parents who had complied with their treatment plans, for example-I could decline to represent Ms. Scott with a clear conscience.

I questioned, however, the lawyer-as-statesman model's assumption that the client does not have the capacity to act as a responsible moral agent. The model suggested that the attorney's role was to train the client to adopt the legal system's values. ${ }^{96}$ Until the client becomes a disciplined moral subject, the attorney has full responsibility for making moral judgments. Neither of these tenets promoted client autonomy, since autonomous moral judgment requires that the attorney and the client have critical distance from their own perspectives. $^{97}$

The lawyer-as-statesman model sabotages the client's right to act autonomously because it employs the ideology-of-domination constructs. The

90. See id.

91. See Kronman, supra note 4, at 112-14, 118-19. Kronman believes the case method teaches the qualities of sympathy, moral detachment, and moral imagination necessary to develop practical wisdom. See id. at 112-14.

92. Simon, supra note 4 , at 1084 .

93. Id. at 1090 .

94. See id. at 1084. Simon attempts to give the attomey some ability to deviate from the law's moral code by framing the legal issue either in narrow or broad terms. See id. at 1107-13. He notes that a lawyer may violate procedural rules if a fundamental legal right is at stake. The more a client's legal claim poses a threat to fundamental values, "the more justified the lawyer is in treating the relevant norms formally." Id. at 1103. Because, however, the attorney has the sole authority to decide when the client's fundamental values are at stake, a client whose moral code seems alien is unlikely to convince her attomey to ignore procedural rules.

95. See Kronman, supra note 4, at 129-32; Simon, supra note 4, at 1131; cf. Charles Fried, The Artificial Reason of Law or: What Lawyers Know, 60 TEX. L. REV. 35, 36-37 (1981) (questioning whether we can assume that the law's moral commands actually reflect the optimal moral calculus).

96. Cf. KRONMAN, supra note 4, at 130-31 (describing the process as collaborative dialogue). Although Kronman argues that the lawyer and the client must be open to changing their views, he notes that if the attorney believes the client has not adopted a reasonable position, the attorney will have to make the decision whether to help the client pervert the law. See id. at 131. Kronman's goal is to convince lawyers that they can take an independent stand to protect the law in these instances.

97. See KUPFER, supra note 33 , at 11. 
model's ample provisions for discretionary moments increase attomey aggressiveness. The lawyer exercises discretion at intake and whenever she believes her client has asked her to perver the legal rules. ${ }^{98}$ William Simon admits that these discretionary moments require the lawyer to weigh the "relative merits of the client's goals and claims."99 Indeed, the model directs the lawyer to evaluate her clients' needs comparatively and to queue clients' cases according to the cases' consistency with the proper operation of the legal regime. ${ }^{100}$ Clients with alien moral codes, or those who threaten to disrupt the law's functioning, must be reeducated about morality or they will be denied representation. The discretionary moments in the model remind the lawyer that the client must submit to her moral assessments.

The client-as-threat construct also encourages the lawyer-as-statesman attorney to act antagonistically toward her client. Anthony Kronman directs the lawyer-as-statesman to deal with the threatening nature of clients by abstracting clients' needs and treating them with emotional distance. ${ }^{101}$ Simon similarly suggests that the lawyer "confront and resolve the competing factors that bear on the internal merits of the client's goals and claims." 102 Both Kronman and Simon make the client's interest a single consideration in a multi-factor assessment. ${ }^{103}$ When the client's interest conflicts with the moral commands of law, the client bows to the need to maintain moral order. The client's alien moral view is preemptively contained because client wishes have relatively little weight in the lawyer's final decision about whether to act.

The system-protector construct also induces the lawyer-as-statesman to be combative. The construct is especially strong in this model because the lawyeras-statesman's stated purpose is to ensure the proper operation of the law. Simon directs the lawyer to choose actions that "promote justice," 10.4 knowing that, because the lawyer-as-statesman cannot distort the law, justice can mean only whatever justice the legal system currently provides. Kronman similarly encourages attorneys to pursue interests that further the shared values of the community. ${ }^{105} \mathrm{He}$ also argues that law represents the community's

98. See Simon, supra note 4 , at $1083,1092-93,1104$.

99. Id. at 1083.

100. See id. at 1091-92; see also KronMAN, supra note 4. at 118 (explaining that when law students are trained to adopt the perspective of judges, they leam to weigh the relative merits of the elieni's interests against countervailing interests).

101. See KRONMAN, supra note 4, at 113-16 (discussing the case method's ability to teach a student to suppress all sympathetic capabilities to experience the judge's perspective of senupulous neutrality). Kronman notes that law students initially fear that the process of empathizing with many people will cause them to lose their souls. See id. at 114-115. He describes how the case method teaches them to engage in disciplined empathy that allows them to treat people's interests with emotional distance. See id.

102. Simon, supra note 4, at I091.

103. Kronman argues that the lawyer-as-statesman uses imagination to inhabit the mind of the client. and of the judge, and then considers what result would benefit the rule of taw in the abstract. See KRONMAN, supra note 4, at 118-19; see also Simon. supro note 4, at 1090 (same). Simon also includes considerations of internal merit and relative merit. See Simon, supra note 4, at 1090-95.

104. Simon, supra note 4 , at 1090.

105. See KRONMAN, supra note 4 , at 4. 
collaboratively derived values. ${ }^{106}$ The lawyer-as-statesman model creates a scenario in which, unless the client can frame her interests in ways that support the legal order, her attorney may feel obliged either to reshape the client's interests so that they comport with legal order, or to refuse to represent her.

The last construct, the call to ideological fidelity, also makes the lawyeras-statesman hostile to the client's perspective. Kronman uses the construct when he argues that lawyers' gravitation toward a hired-gun model has caused them to have identity crises. ${ }^{107}$ According to Kronman, the exercise of practical wisdom, the distinctive mark of a lawyer-statesman, is the sole means of claiming the lawyer's true identity. ${ }^{108}$ Simon also proposes that lawyers adopt only the lawyer-as-statesman model because in his description of the model, he attacks and debunks the premises that inform the other ethics models. ${ }^{109}$ In both scholars' work, the call to ideological fidelity ensures that lawyers do not have disparate experiences that would cause them to challenge the lawyer-as-statesman model. ${ }^{110}$ Additionally, the call encourages attorneys to treat their clients' articulation of alternative moral codes as an opportunity for the lawyers to act out their professional personae and to solidify their claim to the lawyer-as-statesman identity.

\section{B. The Lawyer-as-Friend Model}

The lawyer-as-friend model, which required that I establish "concrete, personal relations"111 with my client, initially seemed to be a kinder, gentler way to approach client representation than the lawyer-as-statesman model. Under this model, I had to determine whether Ms. Scott's moral goals matched my own and whether I could engage in moral dialogue with her. ${ }^{112}$ Once I accepted her case, I was bound to advance her interests as zealously as the law permitted. ${ }^{113}$ Charles Fried, the creator of the model, argues that, ideally, "the

106. See id. at 138.

107. See id. at 122-23 (arguing that one cannot be a good lawyer without the lawyer-statesman's civicminded approach to analyzing legal issues and his ability to detach himself from partisan judgment); see also id. at 3 (arguing that lawyers were happier with their careers when they believed they played the lawyer-statesman role of developing civic ideals).

108. See id. at 16-17.

109. See Simon, supra note 4 , at 1086-87.

110. Simon acknowledges that lawyers rarely adopt a single ethics model in unqualified form, but notes that the models function as heuristics to guide the lawyer's conduct. See id. at 1087.

111. Fried, supra note 1, at 1070.

112. See id. at 1082-84. This discussion simplifies Fried's philosophical discussion of the attorney's moral obligation to give life to the client's wishes. Fried first states that the client's interests are the paramount concem. See id. at 1080-81. He later argues that unless the client's wishes and her desired strategy are consistent with the attorney's personal moral code, the attorney is not obliged to do what the client asks. See id. at 1083 . Fried notes that this formulation may lead the attorney to dominate her client, and he expresses concern that his model may allow a lawyer's "benevolent tyranny over and imposition on his client." Id. at 1066 n.17. He decides, however, "not [to] touch" these problems. Id.

113. See id. at 1081. 
client's needs ... hold the reins" 11 in the relationship, but the "lawyer's liberty-moral liberty" must also be respected. "1s Therefore, according to Fried, the lawyer can end an attorney-client relationship when it is clear that the client is morally reprehensible. ${ }^{116}$

A review of my moral inclinations about Ms. Scolt under the lawyer-asfriend model left me torn. I was sensitive to the fact that Ms. Scott might be a victim of systemic racism. My moral affinity with her, however, ended when she revealed her attitudes with respect to her son Hayden. In my mind, a parent ought to consider the objective best interests of a child. ${ }^{117}$ Therefore, I thought that Ms. Scott should consider that Hayden had the chance to escape the foster care system and be taken into a seemingly ideal home. Ms. Scott's refusal even to examine this possibility made me believe that we could not form a moral dialogue together.

My review of how the lawyer-as-friend model directed one to respond convinced me that any ethics model that required the attorney to factor her own moral conceptions into the representation would undermine client autonomy. When an attorney uses her own moral code to guide a client's case, she is likely to feel personally attacked if the client challenges her moral view. ${ }^{118}$ In addition, given the lawyer's intimate connection to her own moral project, she is unlikely to be able to unpack discontinuities in her moral framework or to know when it is necessary to move beyond her own ethical frame. The lawyer-as-friend model aggravated these problems because it made my moral decisions determinative. If the client disagreed with my moral assessments, I could deny the client assistance or end my representation of her.

In the lawyer-as-friend model, the ideology-of-domination constructs seemed to increase the lawyer's domineering influence. The lawyer-as-friend model is permeated with discretionary moments. The lawyer is entitled to exercise discretion at intake and whenever the client's interests conflict with the lawyer's moral code. Fried explains that the lawyer's power of discretion is her means of expressing her identity. According to Fried, the attorney must "first of all be dear to himself." which] the other things we value radiate." 20 Because Fried links the

114. Id. at 1077.

115. Id. at 1078 .

116. See id. at 1083-84. Fried issues a caveat: The lawyer may be required to offer representation to a repugnant client if the client would otherwise be left unrepresented. See td. at $1074 \mathrm{n} .27$. Even thus obligation, however, is limited to situations in which the client has an essential right at stake. See id. at 1086. Because the lawyer determines what an essential right is, a lawyer who is repulsed by her clienis is more likely to conclude that the client is not pursuing an essentsal interest.

117. See generally JOSEPH GOLDSTEIN ET AL. BEYOND THE BEST INTERESTS OF THE CHILD (1979) (arguing that an attomey can make an objective assessment of the child's best interests).

118. Moreover, a lawyer's personal morality may stmply reflect the gaals of the elite. See Hazard. supra note 2, at $1241,1268$.

119. Fried, supra note 1 , at 1069 . Fried often conflates attomeys' autonomy with thetr ability to judge clients. See id. at 1070 .

120. Id. at 1069 . 
attorney's power of discretion to her identity project, he makes it clear that the attorney will read the client's attempt to challenge the lawyer's discretionary power as an attack on the lawyer's identity.

The client-as-threat construct also leads to attorney aggression under the lawyer-as-friend model. Fried explains that he created the model because he was concerned about the burden of representing clients with moral codes that were alien and threatening. ${ }^{121}$ To avoid this burden, Fried directs lawyers to scrutinize clients' morality at intake. ${ }^{122}$ If a lawyer later finds she has formed relations with a morally questionable client, she can try to change the client's moral perspective. ${ }^{123}$ In this way, Fried ensures that the lawyer treats moral perspectives different from her own as threats. When Fried allows the lawyer to end her representation if a morally distasteful client does not change her mind, ${ }^{124}$ Fried ensures that the client threat can be vanquished.

The system-protector construct in the lawyer-as-friend model also encourages attorney aggressiveness. Under the lawyer-as-friend model, the lawyer is forced to redirect clients who have goals requiring substantive changes in the law. ${ }^{125}$ Although the model allows a lawyer to exploit procedural protections to forward a client's interests, this strategy still serves majority interests. For the lawyer-as-friend is condemned to act as a safety valve, directing clients to marginal legal strategies rather than ones that would truly disrupt the law.

The lawyer-as-friend model requires ideological fidelity as well, sealing a lawyer off from stimuli that would challenge the model. Fried rejects both the lawyer-as-statesman's commitment to justice ${ }^{126}$ and the hired gun's "firstcome-first-serve" approach to choosing clients. ${ }^{127} \mathrm{He}$ suggests that the lawyer-as-friend model provides all the a priori rules a lawyer needs to negotiate her interaction with clients. Fried's claim that the lawyer-as-friend model requires strict adherence suggests that lawyers who encounter clients who are resistant to moral counseling may disrespect clients' attempts to keep

121. Fried was disturbed that a lawyer "can win approval as a good, maybe even great lawyer even though that loyalty is engrossed by . . . distasteful clients." Id. at 1060.

122. See id. at 1078-79.

123. Fried's discussion concentrates on amoral clients. His minimal discussion of the fair client, however, suggests that most often the lawyer will not need to change her own view. In his conclusion, he notes that clients often are already moral subjects who know how to treat others fairly. See id. at 1088.

124. See id. at 1083 \& n.35.

125. Fried explains that zealous advocacy "does not require us to assume that the law is hostile to the client's rights." Id. at 1073. Rather, he explains, "[a]ll we need to assume is that even a system of law which is perfectly sensitive to personal rights would not work fairly unless the client could claim a professional's assistance. "Id. Fried's decision not to direct the lawyer-as-friend to pervert the legal rules ensures that even if the lawyer is sympathetic to a client's cause, she cannot defy the substantive purpose of the law.

126. Fried argues that an enlightened, socially responsible, utilitarian conception of client selection, like the lawyer-as-statesman model, is unsatisfactory. See id. at 1060.

127. Fried also argues that the hired-gun model's propensity to allow lawyers to harm third parties is unacceptable, and shows why his lawyer-as-friend model solves this problem in a more satisfactory manner. See id. at 1064-65. 
their moral assessments private and suggests that they should deny these clients representation.

\section{The Lawyer-as-Hired-Gun}

Dissatisfied with the lawyer-as-friend model's narrow potential for client autonomy, I considered the hired-gun framework to guide my representation of Ms. Scott. Initially, I believed that the model would allow Ms. Scott to act autonomously. The classical hired-gun model suggested that I represent Ms. Scott, regardless of her views. Indeed, under this model all clients are entitled to representation in order to allow them to exercise their constitutional rights. The classical hired-gun model also prohibited me from morally judging Ms. Scott. To ensure that I did not judge her, I was instructed never to engage in moral dialogue with her. In addition, once I began representing Ms. Scott, I was forced to continue, even if I knew she was not considering the moral repercussions of her behavior. For the hired gun "saves the client by all means and expedients, and at all hazards and costs to other persons." 128 She must go on with the representation "reckless of consequences, though it be [her] unhappy fate to involve [her] country in confusion." 129

I noted two serious problems with the classical hired-gun model, however. First, because the classical formulation of the model prohibited moral dialogue altogether, it did not give the client true autonomy, since autonomous action requires that one have the opportunity for reflective judgment. ${ }^{130}$ Second, I noted that most scholars had wholly rejected the classical version of the model on the ground that, because it prevented moral dialogue, it promoted client and lawyer amorality. Indeed, the contemporary description of the hired-gun model remedied this problem. The contemporary reformulation posited that the lawyer should select clients based on her own moral disposition, ${ }^{131}$ should engage in moral counseling of clients, ${ }^{132}$ and could withdraw from representing morally abhorrent clients. ${ }^{133}$

The contemporary hired gun, however, takes away the client's autonomy in the end. ${ }^{134}$ Because the contemporary hired gun chooses clients based on

128. 2 Trial of QueEn Carcline 8 (J. Nightingale ed., London. J. Robins \& Co. Albion Press 1820 . 1821).

129. Id.

130. Without a facilitator to help one engage in critical distinction-making, assessment, and judgment. it is difficult for one to develop autonomous evaluation capacities. See KUPFER, supra note 33, at 45.

131. See Freedman, supra note 7, at 116-17.

132. Cf. Freedman, supra note 57, at 331 (urging lawyers to think of clients as people who need their help).

133. See id. at 333. Freedman explains that if the client has made a material misrepresentation about her situation, and the attomey would not have represented her if the truth had been known, the attomey can terminate the relationship. See id.

134. Freedman changes the hired gun's modus operandi to:

[F]irst, help members of the public to be aware of their legal nghts and of the avalability of legal services ... ; second, advise each client ... regarding the client's legal nghts ... and 
her own moral code, clients who articulate an alien moral code could be denied representation under the model. In addition, because the moral dialogue in this model is based on the attorney's personal moral code, ${ }^{135}$ the model thrusts the client into a hostile confrontation in which she must confront her attorney's moral views. Although the contemporary hired-gun model allows the client to make all moral decisions in the attorney-client relationship, I was convinced that clients would be afraid to express their moral views freely, anticipating that their attorneys might decline to represent them. Moreover, I sensed that clients would be afraid not to acquiesce when their attorneys offered unsolicited moral advice.

The coercive nature of the contemporary hired-gun model is directly attributable to its use of ideology-of-domination constructs. Monroe Freedman, the main proponent of the contemporary hired-gun model, argues that the attorney has four discretionary moments: ${ }^{.136}$ (1) at intake; (2) with the client's consent; (3) when withdrawal can be accomplished without significant harm to the client; and (4) when the lawyer has been induced by the client to take the case on the basis of material misrepresentations about the case. ${ }^{137}$ Because these discretionary moments allow the lawyer to sever her relationship with the client when the lawyer is repulsed by moral dialogue with the client, they tend to eviscerate Freedman's claim that the hired gun does not supplant the client's power of moral decisionmaking. If the client dares to stake out a moral position contrary to her lawyer's, she has no assurance that her attorney will continue to represent her. ${ }^{138}$

The client-as-threat construct is more subtly expressed under the contemporary hired-gun model. The model suggests that a client who lives by a moral code that seems alien to her attorney may be denied representation. ${ }^{139}$ In addition, if the attorney determines that the client is an alien moral subject during her representation of the client, she may end the relationship. The threat construct becomes clearer when one recalls how the classical hired gun treated clients with unusual moral codes: by maintaining a

moral obligations; and third, zealously and competently use all lawful means to protect and advance the client's lawful interests as the client determines those interests to be .... Freedman, supra note 24 , at 470 (emphasis added).

135. Freedman does not explicitly state that the lawyer must base her moral counseling on her own moral code; nevertheless, it is an unstated premise in his discussions. See, e.g., Freedman, supra note 57 , at 334-36; id. at 335 (arguing that lawyers "have a professional obligation to counsel [a] client to do what [the lawyer] believe[s] is the right thing").

136. At first glance, the contemporary hired gun may seem to have only one discretionary momentat intake. Freedman argues that, "[u]ntil the lawyer-client relationship is contracted, . . until, that is, the lawyer induces another to rely upon his or her professional knowledge and skills-the lawyer ordinarily acts entirely within the scope of his or her own autonomy." Id. at 332 . He nonetheless mentions three additional instances when the lawyer can resist a client's wishes. See id. at 332-33.

137. See id. at 332-33.

138. Freedman distinguishes his model from the attomey-as-friend model by arguing that unlike the friend, the hired gun will not gently cajole a client into a course of action. She can merely highlight moral concerns. See Freedman, supra note 24, at 471.

139. See Freedman, supra note 57 , at 332. 
non-judgmental stance. In contrast, the contemporary hired-gun model advises lawyers to handle unfavorable clients in much the same way as the other models do: by ending the representation. ${ }^{140}$

In both the contemporary and classical versions of the hired-gun model, the attorney is a system protector. Her allegiance is to the adversary system. ${ }^{141}$ Freedman explains that "[t]he way in which [hired-gun] lawyers recognize, honor, and enhance the rule of law in our society is by serving individual clients. That is, ... by enhancing the autonomy of each individual." ${ }^{142}$ Because the hired-gun lawyer's focus is on forcing the legal system to engage disparate views, she will not take the time to ensure that the client is fully aware of her motivations for seeking certain goals or the repercussions of these motivations. Rather than making the client responsive to the alien moral order represented by the law or making the law cognizant of the client's contrary moral views, the hired gun simply keeps the adversarial system functioning.

The hired-gun model is also hostile to other ethics models. Freedman argues that the hired-gun role is derived from the Constitution itself; consequently, he argues, it is the only way that the lawyer can uphold the ideals of advocacy. ${ }^{143}$ Advocates of the contemporary hired-gun model reject alternative models on the ground that their intrusive versions of moral dialogue inevitably lead to client domination. ${ }^{144}$ Still, since the hired-gun attorney uses her own moral code to suggest moral considerations, she also runs the risk of dominating her clients. Thus far, no hired-gun advocate has suggested changes to the model that would prevent the lawyer from passing judgment on the client for her moral views.

\section{RECOGNIZING AND ESCAPING HEGEMONY}

One indication of the hegemonic nature of the ideology of domination is that the ideology entraps oppositional scholars as well as mainstream ethicists. Oppositional scholars complain that the new models they create inevitably lead to client subordination. In addition, oppositional ethics scholarship exhibits a characteristic hesitance and tentativeness that is only partially attributable to its postmodern commitments. ${ }^{145}$ Some of this tentativeness is traceable to

140. See id.

141. See Freedman, supra note 24, at 469.

142. Id. at 471 . Freedman cites a series of constitutional cases to suppon his view, including Lassiter v. Department of Social Services, 452 U.S. 18 (1981); and Goldberg v. Kelly, 397 U.S. 254 (1970). See Freedman, supra note 24 , at 468-69 \& nn.7-8.

143. See Freedman, supra note 24, at $468-69$.

144. See Freedman, supra note 57, at 334-36 (challenging such models as patemalistic and elitust).

145. See, e.g., Lopez, supra note 20, at 1716 (describing progressives' commitment to the postmodem view that knowledge comes from examining multiple, partial perspoctives): White, supra note 23. at 854 (same). 
scholars' difficulties in getting beyond their conditioning under the ideology of domination. This part examines signs that the ideology-of-domination constructs are present in oppositional scholarship and shows how they limit scholars' abilities to create models that facilitate client autonomy. Additionally, this part notes instances in which scholars have escaped the ideology-ofdomination constructs. It concludes by offering scholars general strategies they can adopt to avoid ideology-of-domination constructs in their work.

\section{A. The Ideology of Domination in Oppositional Scholarship}

Of all the ideology-of-domination constructs, oppositional scholars seem least inclined to give up their use of the discretionary-moment construct. Gerald López, creator of the rebellious-lawyering model of ethics, ${ }^{146}$ argues that discretionary power gives a lawyer her sense of identity. ${ }^{147} \mathrm{He}$ unabashedly rejects the idea that lawyers should "disavow their legitimate claim on giving life to their convictions through their work, or deny the inevitability of expressing their values through choices and judgments they make in choosing and working with clients." ${ }^{148}$ He notes that progressives who want lawyers to give up discretion are seen by their worst critics as wanting to "level and neuter lawyers, leaving them without convictions and commitments." "149 Instead of trying to dismantle the construct, Lopez argues that the lawyer can exercise discretion to determine a client's ends and goals by having a sense of what the community's interests are. Unfortunately, Lopez fails to address the fact that the lawyer's political commitments to the community may lead her to subordinate individual clients' interests. Indeed, the strategies the lawyer suggests will be based on her knowledge of the limited portion of the community with which the lawyer is in dialogue. ${ }^{130}$

146. At present, the rebellious-lawyering model is the most popular oppositional ethics approach. Lopez created the model in part because he recognized that progressive lawyers were struggling against the regnant or traditional model of lawyering. See L6pez, supra note 20, at 1606, 1608. The regnant model he describes encodes ideology-of-domination constructs. The rebellious-lawyering model posits that lawyerclient relationships should be collaborative and nonhierarchical and that the lawyer shares the political commitments of the community she serves. The rebellious lawyer uses a brand of political morality, derived from discussions with community members. See id. at 1608, 1613 n.17.

147. See Lopez, supra note 73, at 318. CRT scholar David Wilkins, like Gerald Lopez, argues that the lawyer should use her community allegiances to identify the moral values used in practice. See Wilkins, supra note 3, at 1985 (arguing that black corporate lawyers have a responsibility to express their allegiance to poor black communities when working with corporate clients). He believes that the profession ensurres its credibility by accepting moral responsibility for client actions. See Wilkins, supra note 61 , at 473 . This perspective is markedly similar to Fried's traditionalist view. See Fried, supra note 1, at 1069-70.

148. Lopez, supra note 73 , at 318.

149. Id.

150. See Tremblay, supra note 10 , at $68 \mathrm{nn} .184-85$ (noting that there can be a conflict between an individual poor client's goals and the long-term interests of poor communities). Indeed, this directive can require the lawyer to pursue a variety of ends. See id. at 58,59 (noting that Lopez's requirement that tho lawyer reflect the moral values of the community she serves could suggest helping poor persons facing more powerful people or helping clients who reflect the community's needs). 
Notably, in some oppositional scholars' work, the discretionary moment becomes part of the lawyer's desire to control client means rather than client ends. Because oppositional scholars feel an affinity with poor communities and focus on discussions of poverty lawyering in their work, they do not often challenge slients' substantive goals. Oppositional scholars are attentive to, and troubled by, their tendency to shape clients' means: namely, how much power the client will have to tell her story. ${ }^{151}$ Oppositional scholars complain that the default model of progressive lawyering entirely usurps discretionary power from the client and gives the lawyer the power to determine what moral code animates the client's story. ${ }^{152}$ Although the oppositional scholars have tried to find ways to help the lawyer translate her client's story so that she gives the client more power, their discussions of power negotiation seem largely reminiscent of traditionalists' discussions about how to negotiate power relations in the attorney-client relationship. ${ }^{153}$

The client-as-threat construct is also well entrenched in oppositional scholars' work, although they are struggling against it. CLS advocate Peter Margulies has described his frustration with his clinical students because they often see their poor clients as threatening "Others."154 Lopez notes that while progressives claim that they are not repulsed by their clients, they usually harbor closet fears of them. ${ }^{155}$ To get beyond this mistaken perception, Lopez encourages lawyers to develop ties with their clients' communities. ${ }^{156}$ Other scholars have pursued a less successful strategy: calling for increased lawyer empathy. ${ }^{157}$ Inevitably, however, there are limits to any person's ability to

151. See Anthony V. Alfieri, Impoverished Practices, 81 GEO. LJ. 2567, 2567 (1993) [hereinafter Alfieri, Impoverished Practices]; Anthony V. Alfieri. Stances, 77 CORNELL L. REV. 1233, 1233 (1992) [hereinafter, Alfieri, Stances]

152. See Lopez, supra note 20 , at 1608.

153. Anthony Alfieri catalogues progressive scholars' attempts to address the lawyer's discretionary power to tell the client's story. See Alfieri, Stances, supra note 151, at 1234-40. He surveys work in which oppositional scholars describe lawyer "play," in which lawyers "shift[l the dominant-dependent hierarchy of the lawyer-client relation . . . to afford the client room to speak." Alfieri, supro note 32, at 2136-37. Many progressive scholars attempting lawyer "play" end up dominating their clients. See Alfieri, Stances. supra note 151, at 1235 (documenting one lawyer's failure at translation); Lucie E. Whitc. Subordination. Rhetorical Survival Skills, and Sunday Shoes: Notes on the Hearing of Mrs. G., 38 BUFF. L REV. 1 (1990) (discussing the author's failure to translate her client's story properly). These scholars' descnptions of play and lawyer-client translation are simply a more poetic manner of discussing the attomey-client baule of wills.

154. Margulies, supra note 22, at 695.

155. Lopez explains that oppositional scholars find it difficult to believe "in the ingraned virtue and insight of all poor people-especially poor people of color." López, supro nole 73, at 317.18. Lopez himself characterizes client contact as a "pain dragging" experience that can be "hard and sometumes downight scary." Id. at 321 .

156. See id. at 318-19. Charles Ogletree also argues that attomeys should become invested in the communities they serve. See Ogletree, supra note 19, at 1291-92. Interestingly, a white middle-class student attempting to implement Ogletree's advocacy model with his black impoverished clients rejected the model because he found his clients' moral calculuses alien and self-defeating. See Roben Rader. Confesstons of Guilt: A Clinic Student's Reflections on Representing Indigent Cruminal Defendants. I CLINICAL L REV. 299 (1994).

157. See, e.g., Delgado, supra note 22, at 68 n.25 (cataloguing fernınist and CLS calls for empathy): Toni M. Massaro, Empathy, Legal Storytelling, and the Rule of Law: New Words. Old Wounds. 87 MicH. 
empathize by imagining herself in the place of another. These limits would be unproblematic in relationships in which parties have equal power and are unafraid of one another. ${ }^{158}$ Lawyers, however, use their empathic sensibilities to nullify clients' threatening natures. In this context, empathy has become a tool of lawyer domination. ${ }^{159}$ The client is forced to become what the attorney believes she must be, in order for the attorney to feel comfortable representing her. Frustrated by their inability truly to understand their clients, or repulsed by the imaginative project of getting to know "the Other,"160 scholars are backing away from the empathy concept. ${ }^{161}$ Oppositional scholars, however, need to consider whether the fear that inspires their empathy is the problem, rather than assume that empathy is a means of domination.

Oppositional scholars have had the most success in moving beyond the system-protector construct. When scholars fully reject the construct, the result is transformative. ${ }^{162}$ López was one of the first scholars to reject the systemprotector role. He argues that legal remedies are sometimes not enough ${ }^{163}$ and that established legal structures are sometimes the problem. ${ }^{164}$ Armed with these conclusions, López expands the lawyer's role to include activities whose aim is transforming the law. Under his model, the lawyer does work traditionally considered the ambit of social workers, lobbyists, and community organizers. ${ }^{165}$

The call to ideological fidelity in the oppositional camp is less strong because no oppositional model has become hegemonic. Oppositional scholars,

L. REV. 2099, 2106 (1989) (explaining that CLS and feminist scholars' failure to define empathy in their work has led them to place unwarranted emphasis on the concept).

158. Toni Massaro argues that only after we are conscious of "the lines of our personal cmpathic limitations may we develop more realistic . . . proposals that better account for people's predisposition not to see beyond their own concerns." Massaro, supra note 157, at 2123.

159. See Delgado, supra note 22 , at 70 . Delgado argues that "[r]eal empathy" is rarely required in oppositional ethics models. Id. at 75. Instead, because many progressive lawyers see their clients' experiences as radically alien, they inevitably employ a colonizing, imperial version of empathic relation. Delgado warns that "[t]he most unsympathetic thing [white middle-class lawyers] can do is think [they] have empathy with those of a radically different background. [They] can easily end up hurting [their clients]." Id. at 72.

160. Lopez, supra note 73, at 319 (describing progressive scholars' resistance to emotional connection with poor clients of color). The term "Other" is explained by Edward Said. See EDWARD W. SAID, ORIENTALISM 325-26 (1978) (explaining how Western culture constructs persons of less favored race, gender, and class status as foreign, threatening subjects).

161. See, e.g., Alfieri, supra note 32, at 2129 (describing the inherent limitations of empathic connection and suggesting other strategies that can empower clients).

162. Not all scholars are convinced that lawyers can abandon this function. David Wilkins makes an ambivalent argument for the construct, explaining that the legal system is not "entitled to survive regardless of its social utility," although the lawyer must maintain her commitment to the law and help the clicnt find an established cause of action to address her injuries. Wilkins, supra note 61 , at $468 \mathrm{n} .21$. Alfieri suggests that lawyers view the system's codification of values "with suspicion." Alfieri, supra note 32, at 2134. It is unclear, however, what a suspicious lawyer should do when the law harms her client.

163. See Gerald P. López, The Work We Know So Little About, 42 STAN. L. REV. 1, 10 (1989).

164. See id. at 9.

165. See id. (pointing out lawyers' multiple roles); Lucie E. White, To Learn and Teach: Lessons on Driefontein on Lawyering and Power, 1988 WiS. L. REv. 699, 724 (describing the lawyer as a political organizer). 
however, are beginning to develop tenets exclusive to the progressive model of lawyering. ${ }^{166}$ The oppositional camp might in the end reject the ideological fidelity construct because its projects are based on poststructuralist theory, which suggests that any unitary, totalized vision of the world is dangerous and constraining. ${ }^{167}$ Still, oppositional scholars have not concentrated on the identity-performance theories in poststructuralism and have been silent about how calls to ideological fidelity animate individuals' identity-performance drives. Indeed, oppositional scholars are increasingly adopting the second tenet of ideological fidelity: A professional ethics model identity is a valid method of expressing one's personal identity. ${ }^{168}$ They have not discussed how an attorney's desire to act out her moral and political commitments in her professional life can lead her to dominate clients. If oppositional scholars continue to believe that lawyers can use clients in their identity projects, they will inevitably come to believe that lawyers need a single identity or professional paradigm around which to organize their identity performances.

Oppositional scholars' inattention to the limitations that the hegemonic constructs impose on discussion stems in par from their failure to engage in dialogue with traditionalists. ${ }^{169} \mathrm{~A}$ heated exchange deconstructing the dominant models might have revealed the operation of these constructs sooner. Because oppositional scholars have failed to deconstruct the traditional ethics models, many hegemonic constructs from traditional ethics approaches have surfaced in their models. As Gramsci predicted, once hegemony takes hold in oppositional thought, debate drifts to tangential issues. ${ }^{130}$ Oppositional scholars should consider whether their current debate about lawyer translation of client stories and lawyer empathy can ever give birth to revolutionary change. ${ }^{171}$ If these discussions are products of hegemony, the central tenets of legal ethics that cause the domination of clients will go unexamined.

\section{B. The Way Forward}

Given the powerful hold the ideology of domination has on legal ethics, autonomy-based critiques must, at a minimum, be highly suspicious of ethics

166. Lopez argues that he can distinguish between "those who are with us and those who are not." López, supra note 73 , at 323 . He posits that anyone who refuses to engage in community dialogue is not a rebellious lawyer. See id.

167. See White, supra note 23 , at 854 .

168. See, e.g., David R. Esquivel, The Identity Crisis in Public Inverest Law, 46 DLKE LJ. 327. 330 (1996) (arguing against a hired-gun conception of lawyering because it does not give poverty lawyers sufficient justifications for their work); Wilkins, supra note 3, at 2022 (argung that his ethics model allows "black corporate lawyers space to pursue their obligations to the black community free from professional criticism").

169. Cf. Brown, supra note 22, at 530 (arguing that CRT accounts of racism uould be improved by taking into account traditional scholarship on racism).

170. See Thomas Nemeth, Gramscl's Philosophy: A Critical Study 17 (1980).

171. Cf. Alfieri, Impoverished Practices, supra note 151, at 2694 (expressing ambivalence about the success of lawyer translation); White, supra note 23 , at 854 . 
models that privilege the ideology-of-domination constructs. Scholars should be wary of models that (1) privilege attorney discretion; (2) depict clients as threats; (3) encourage the lawyer to act as a system protector; and (4) endorse ideological fidelity. In addition, scholars should be leery of ethics models that ask the lawyer to act out her identity by forcing a client to submit to a predetermined moral code. ${ }^{172}$ Unless scholars are vigilant about these constructs, they will be unable to theorize ethics models that promote client autonomy. As a first step, scholars should find ways to create models that avoid the constructs altogether. Ideally, however, they should analyze the ideology-of-domination constructs to determine why these constructs have persuasive power for traditional ethics scholars and for the majority of lawyers. ${ }^{173}$ Once we understand the reasons that these constructs are popular, we can create new ethics models that address these issues without subordinating clients. Our goal should be to address these concerns in a way that allows attorneys to promote egalitarian social relations.

\section{THE ETHICAL MIRROR MODEL}

To demonstrate how overcoming these constructs would allow us to create a new affirmative vision of ethical lawyering, this part introduces the ethical mirror model. The ethical mirror model is an ethics paradigm that is free of the ideology-of-domination constructs. As the model moves beyond these constructs, it transforms the attorney-client relationship into a space where a client can learn how to engage in autonomous moral decisionmaking. The ethical mirror model is intended to be a thought experiment that explores what it would mean for lawyers truly to facilitate their clients' ability to engage in autonomous moral decisionmaking. The model shows that lawyers can participate in moral dialogue with clients without turning the interaction into a coercive and judgmental experience.

\section{A. Guiding Principles}

The ethical mirror model is designed to serve one paramount goal: It assists the client as she develops her capacity for autonomous moral judgment. The model takes its definition of autonomous judgment from the Kupfer definition described above. ${ }^{174}$ Specifically, the model posits that the lawyer's

172. Catherine Hall warns that identity construction is often based on the idea that "I know who I am [because] I know how and why I have power over you." Catherine Hall, Missionary Stories: Gender and Ethnicity in England in the 1830s and 1840s, in CULTURAL STUDIES 240, 241 (Lawrence Grossberg et al. eds., 1992).

173. Ideology does not wholly manufacture issues, but rather it translates amorphous concems into concrete problems. See EAGLETON, supra note 36, at 14-15. The ideology of domination simply articulates lawyer concerns in ways that assist in maintaining our country's classist social order.

174. See supra text accompanying notes 33-35. 
role is to assist clients in developing moral decisionmaking skills. The cognitive skills the attorney helps the client develop include how to anticipate the moral repercussions of her acts, how to discriminate between different options based on their moral repercussions, and how to recognize and resolve inconsistencies in her moral vision.

The model places attorneys in this role because legal education aptly prepares lawyers to help others rationalize and instrumentalize amorphous and sometimes conflicting values. ${ }^{175}$ According to Austin Sarat and William Feistiner, lawyers think about client motives in "rational-purposive terms," "776 meaning that a lawyer can look at the client's articulated interests "in terms in which technical rules and a problem solving orientation are more important than [the client's] emotional reactions and justifications of self." ${ }^{77}$ This orientation helps lawyers make sense of clients' moral goals without requiring lawyers to agree with those goals on a personal or moral level. Additionally, Sarat and Felstiner explain that lawyer-client interaction helps the client develop her perspective of why others act in the world. "What lawyers tell their clients about social relations, how they respond to client questions about the motivations of other people, structures, at least in part, the way in which clients "experience and perceive relations with others."178 Therefore, the lawyer is in a unique position to help the client create a moral universe: She should empathize with, and assess the interests of, other players involved in the client's legal claim.

The ethical mirror model imposes four requirements on the attorney. First, the attorney must be willing to suspend her moral judgment of the client. Second, she must enter into moral dialogue with the client. Third, she must be able to don different ethical personae as the client demands changes in the ethics approach used in the representation. Fourth, she must develop a facility for explaining the ethics models and options to clients. If the attorney can master these skills, she can help clients make informed and considered moral choices. The requirement that the attorney be able to change ethics personae, or "cycle" through ethics models, is perhaps the most difficult of all the requirements. It is essential, however, that lawyers master this skill in order to allow a client to change the ethical perspective used in her representation without changing her attorney. This cycling process also helps the lawyer maintain a distanced perspective from each ethics approach, giving her an opportunity to see the strengths and weaknesses of each ethics model.

175. Law school teaches one how to analogize between different scenarios, to ferret out flaws in seemingly logical arguments, and to instrumentalize general values. Since legal education focuses more on these issues, rather than on substantive issues in morality, a lawyer is better qualtifed to serve as a moral facilitator than as a moral judge.

176. Sarat \& Felstiner, supra note 15 , at 405.

177. Id.

178. Id. (internal quotation marks omitted). 
The basic rules of the model are as follows: At intake, the ethical mirror model attorney asks the client whether she wants to use one of the traditional ethics models or if she would like to use the ethical mirror model approach. If the client chooses the ethical mirror model, the attorney asks the client to outline a moral view to guide her case. The attorney then explains how the client's moral vision provides rules for how the client will treat others. The attorney formulates a legal strategy based on the client's chosen ethics approach. The attorney informs the client that she can change the moral vision that guides the case if she is troubled by the vision's repercussions. The client is required to redescribe her ethical vision at major stages in the representation, in order to identify and resolve any inconsistencies in her perspective. The main goal in the attorney-client relationship is to ensure that the client becomes accustomed to anticipating and addressing the moral repercussions of her actions. ${ }^{179}$

The ethical mirror model imposes requirements on clients as well. Clients must agree to enter into moral dialogue with their attorneys. Additionally, they must commit to developing cohesive moral personae. The model requires clients to commit to moral dialogue because this is the only way their attorneys can be sure that clients are engaging in reflective judgment. As Kupfer explains, autonomous judgment occurs only after the individual has made informed reflective choice. ${ }^{180}$ The model requires that the client create a consistent and cohesive moral persona because it is likely that, as clients recognize that a given ethics persona has unpleasant or costly requirements, they may be tempted to vacillate between models, using whichever ethics persona best serves their instrumental goals at a given time.

The ethical mirror model is radically different from the prevailing ethics models because it gives the client the power to control which ethics vision guides her case. No matter which ethics model the client chooses, she has exercised her right to determine the scope of the moral dialogue. The client can decide whether she is best served by a discussion of the legal system's values, her lawyer's values, or her own values. Regardless of her decision, the client has an opportunity to work with a facilitator to assist her in seeing the liabilities and benefits of her chosen moral calculus.

\section{B. Escaping the Ideology of Domination}

The ethical mirror model radically restructures the attorney-client relationship because it stakes out a position in opposition to the ideology-ofdomination constructs. First, the model changes the discretionary moment from

179. See infra Section IV.D for a more detailed discussion of the ethical mirror model in the context of different types of practice.

180. See supra text accompanying note 35 . 
a moment in which the lawyer examines her chosen moral code into a moment in which the client discusses her independently constituted moral ideas. The ethical mirror model also subverts the client-as-threat construct. The attorney never feels as though her moral code is being challenged because she is not required to use her moral dispositions to regulate her practice. In addition, the model enables the lawyer to listen to, and not to feel threatened by, alien moral codes because the attomey has worked under a variety of ethics models. Finally, the lawyer's moral code is likely to be enriched because her discussions with clients continuously give her fresh insights about morality.

The ethical mirror model also challenges the system-protector construct. The model rejects the notion that the law enacts a correct moral code and posits that the client is the person who establishes what justice is. Under this model, the law is simply a means for the client to achieve her just ends. The attorney, therefore, is an agitator who aggressively works with her client to shape the law. Under this model, the attorney is more inclined to exploit procedural protections, to stretch causes of action to address harms that the legislature has not anticipated, and to bring cases testing the constitutionality of laws that burden her clients' interests. In addition, the model advises the lawyer to help clients who are not interested in aggressive legal strategies ${ }^{181}$ find other means of changing the law. ${ }^{182}$

The ethical mirror model also avoids the dangers of ideological fidelity. The model rejects the idea that one perspective can give an attorney all the insights needed to represent a client. The ethical mirror model requires that the attorney cycle through different ethics models at her clients' request, making attorneys more resistant to ideological conditioning. In addition, the attorney's cycling through the various models prevents her from using her practice to act out her moral identity. The lawyer will find that she cannot engage in a static set of repetitive identity-performance practices. These practices may be essential for identity construction; one must remember, however, that they can easily lead to the subordination of others.

The ethical mirror model also capitalizes on the poststructuralist insights that have informed oppositional ethics scholarship. The model is based on the

181. Admittedly, the strategies enumerated above reflect an idealisuc notuon of adrocacy The altorney may not have the resources to adopt aggressive strategles in every case. She is also required to tell the client that the legal system will often ignore the pleas of people who try to challenge a law Mlost importantly, the client may decide that she does not have the emolional stamun, ume, or resources to launch a frontal attack on the legal rules. Since the ethical mirtor model is premised on the idea of eltent autonomy, the attomey should defer to the client's decision about whether to engage in an aggressive or conservative legal strategy.

182. When the client requests a conservative case strategy, the attomey still may connect her client with grassroots lobbying organizations and impact litigation groups. Cf. Lopez, supra note 20, at 1610 (criticizing regnant or traditional models of lawyering for falling to make connectuons with grassroots organizations). These groups can help clients find ways to transform hostllity toward the law into strategies that pose less personal risk and, because the groups have few procedural rules, clients can express theır experiences more authentically than in traditional litugation contexts. 
idea that theoretical perspectives are partial ${ }^{183}$ and therefore must be regenerative $e^{184}$ to allow persons silenced by a theory to collaborate periodically in its reformulation. The model instrumentalizes these insights. For example, because the attorney uses different ethics models each day, the model makes the lawyer recognize that her perspective is always partial. Moreover, because the different models allow an attorney to experience conflicting moral visions, the attorney has a broader and more nuanced understanding of the moral universe than she would under a single ethics model. Finally, by making lawyers assist clients in creating their own moral visions, the ethical mirror model ensures that the attorney will be exposed to the regenerative influence of disempowered persons.

\section{Criticisms of the Model}

Some might argue that the ethical mirror model is overly optimistic about clients' abilities to engage in autonomous moral judgment, particularly in its assumption that clients will have empathy for others. The ethical mirror model, however, promises to cultivate clients' capacities for empathy by requiring attorneys to remind clients continuously of how acts have material repercussions for others. Even clients with strongly antisocial and misanthropic moral views are likely to be susceptible to the model's influence. Requiring a person to examine fully the inconsistencies in, and repercussions of, her moral code may be more persuasive than forcing her to listen to the often pedantic unsolicited preaching of an attorney.

The ethical mirror model may be difficult for lawyers to implement. A lawyer may find that her client impetuously demands that she change models without fully recognizing the import of her decision. Some confused clients may simply want to experience each of the various ethics models. Others may simply jump ship from a model when they realize that it will not allow them to act as they originally desired. ${ }^{185}$ In many cases, these problems will stem from the lawyer's failure to explain the models adequately to her clients. When the lawyer believes she has a client who is strategically changing ethics views, however, she can increase the costs of changing models. ${ }^{186}$

183. See, e.g., id. at 1716 (describing the commitment in the new advocacy literature to the slow learning that comes from multiple, partial perspectives); White, supra note 23, at 854 (same).

184. See López, supra note 20, at 1606, 1716 (arguing that lawyers, like all people, have incomplete partial knowledge, and that they must "collaborate," "resolve," and "accommodate" differences in perspectives in an "open ended interaction" to gain new insights); $c f$. White, supra note 23, at 855 (describing theory as an ongoing practice of reflection and conversation).

185. Thanks to Professor Dennis Curtis for pushing me on this point.

186. An attorney can either require the client to be bound by a given moral framework for a sct time period or require the client to engage in extensive dialogue about the client's decision before the lawyer shifts models. 
Critics may also charge that the ethical mirror model is a form of domination because it allows the attorney to bring a false coherence to a client's often contradictory moral goals. ${ }^{187}$ The attorney, however, makes the client responsible for building a cohesive vision. Her only role is to point out the client's inconsistent statements and to ask her to clarify her position. If the attorney is unable to give true expression to the client's moral view, the client can always direct the attorney back to another model of representation, including a lawyer-as-statesman, lawyer-as-friend, or hired-gun approach.

\section{The Ethical Mirror Model in Action}

\section{Poverty Law Practice}

Arna Scott walks into my office. I ask her what she wants. She wants her son back. I ask her whether she believes her cause is just and, if so, to explain why. Specifically, I invite her to define her moral universe and to explain the case to me in terms of her ethical vision. I explain to her that if she is uncomfortable with this kind of moral dialogue, there are other approaches we can use. I explain to her that I could act as a lawyer-as-statesman and counsel her about the morality under the law. Or, I could act as a lawyer-as-friend and counsel her based on my own moral code. Finally, I could act as a hired gun, which would require me to give her my moral insights in a less aggressive fashion. Ms. Scott chooses to use a mode of representation that employs her own independently constituted moral view. I remind her that she can change the moral code we use at any time during the representation.

Ms. Scott explains that, from her perspective, she represents the cause of justice. She believes that she has been victimized three times. First, she was brutally beaten by her child's father. Second, she was branded a suspect mother by the hospital workers from whom she asked for help. Third, her treatment plan imposed paradoxical requirements: Leave Hayden's father, but maintain stable housing; finish a drug treatment plan, despite the fact that none will admit someone who appears to have mental health problems. ${ }^{188}$ In her mind, it was cruel to make the treatment plan her sole source of services when it was also the mechanism that recorded her troubles as grounds for the state to keep Hayden.

I ask Ms. Scott if her experiences have taught her any moral principles that she wants to use in her representation. Ms. Scolt explains that her experiences

187. I thank Professor David Wilkins for offenng this counterargument.

188. Ms. Scott's DCF case file indicated that she was "mentally fragile." but it made no special provisions for mental health treatment. Over the course of my representation of her, several drug treatment programs expelled her because they perceived that she was mentally ill. For a discussion of thus problem. see Christina Victoria Tusan. Homeless Families from 1980-1996: Casualstes of Declining Support for the War on Poverty, 70 S. CAL. L. REv. 1141, 1224-25 (1997). 
have led her to believe that the state has betrayed her. In her mind, the State of Connecticut broke its promise to her. She was told that the state would try to keep her with her son and help her to be a better mother. She feels that the state then decided she was beyond help and decided to throw her away. She feels her position is right because the state has broken its word.

I explain to Ms. Scott that under the ethical mirror model, I am a tool that will allow her to act in the legal system. My only requirement is that she engage in moral dialogue with me to ensure that she recognizes the ethical repercussions of her actions. I explain that her moral vision will determine what goals we set and how we present her story to the court. I remind her that, before we pursue any major course of action, we will talk about the moral effects of our strategy in order to determine if she is using a consistent, reflective moral view.

I brief Ms. Scott about how her chosen moral view will affect others. Her vision requires that we exploit every legal right she has in order to hold onto her son. We will do everything in our power to force the state to live up to its stated goal of reforming her as a parent. We will end the representation when Hayden is in a place that addresses both her needs and his. I point out to Ms. Scott that Hayden may be injured by our choices. We may prevent him from being adopted by a foster mother to whom he has strong emotional ties. I also note that our strategy will cause the foster family pain. Ms. Scott says that she is comfortable with the moral repercussions of her acts. We spend the remainder of our meeting turning her moral strategy into a legal strategy. ${ }^{189}$

At the close of our meeting, I remind Ms. Scott that if she becomes uncomfortable with how our actions affect others, we can change the moral view guiding the representation or use her moral map to develop less aggressive ways to achieve our goals. I explain to her that at each pivotal step in the representation, I will ask her to outline her moral vision to ensure that she uses a consistent moral approach. I reassure her that I will continue representing her until her goals are met, I am taken off the case, or she stops contacting me. I also brief her about ways she can work to change the child protection laws, namely by participating in legislative advocacy groups.

\section{Institutional Clients}

The ethical mirror model is designed to address the needs of poor individual clients. It can also be used, however, to represent corporate entities. ${ }^{190}$ Admittedly, it may be difficult to get a group of officers and

189. An attorney may also discuss how a client's choices will affect the legal system. Because Ms. Scott felt the state had betrayed her, however, it seemed inappropriate to voice this concem.

190. Fried explains that models based on single-person representation can be extended to understand corporate clients. In his view, "corporations and other institutions are only formal arrangements of real persons pursuing their real interests. If the law entitles real persons to pursue their interests in these 
board members to agree on a single ethics vision. ${ }^{191}$ Business ethics scholars suggest that the attorney look to internal compliance codes, ${ }^{192}$ the corporate charter, ${ }^{193}$ or executive officer oaths ${ }^{194}$ to identify the moral rules that bind the corporate officers in a common vision. While some may argue that these materials insufficiently represent the interests of shareholders and other persons with an interest in the corporation, ${ }^{195}$ "informal consent to these rules can be assumed to the degree that such values are selected, published and adhered to by successive layers of the corporation." 196 If persons with an interest in the corporation object to these moral guidelines, they have ample opportunity to respond to and challenge these strictures.

A corporation that uses counsel employing the ethical mirror model will enjoy numerous benefits. The model can help officers avoid liability, since they may more often act in good faith because their counsel will force them to reflect on the moral repercussions of their actions. In addition, participation in moral dialogue may foster in officers an increased sense of corporate responsibility. Lastly, a corporation with a mature, developed moral code will enjoy increased stature in the eyes of government and the public. ${ }^{197}$

\section{CONCLUSION}

Ideology-of-domination constructs dominate traditional scholars' work. As a result, scholarly debate focuses on the possibility that clients will pose threats to the moral and legal order, rather than on examining how clients' perspectives might enrich our collective understanding of morality. ${ }^{198}$ Gramsci explains that progressive theorists must deconstruct old philosophical

complex forms, then why are they not entitled to loyal legal assistance . . . . Fned, supra note 1, at 1076. Additionally, I would add, if these groups are allowed to act autonomously, they should be required to articulate a cohesive moral vision as well.

191. But see E. Michelle Rabouin, Walking the Talk: Transforming Law Students tnto Ethical Transactional Lawyers, 9 DEPAUL BUS. LJ. 1, 3 (1996). Some scholars argue that businesses themselves are looking to attorneys for ethical guidance, claiming that the nouson that the firm is simply an organizalion created to serve profit interests of shareholders without breaking the law has become passt. See id. at 29.

192. See, e.g., Michael Goldsmith \& Chad W. King. Policing Corporate Crime Datc: The Dilemms of Internal Compliance Programs, 50 VAND. L. REV. 1, 1-2 (1997) (discussing the costs and benefits of internal compliance programs).

193. See Rabouin, supra note 191 , at 30.

194. See id.

195. But see id. at 26 (arguing that corporations contain several constituencies, including corporate officers and stakeholders).

196. Id.

197. Since many of the corporate codes and internal compliance malerials are subject to public review. companies already have a vested interest in ensuring that their moral stalements of purpose will withstand scrutiny.

198. A great number of ethics discussions simply address which of the dominant ethucs models is the best. See, e.g., Robert J. Condlin. Bargaining in the Dark: The Normative Incoherence of Lawyer Dispute Bargaining Role, 51 MD. L. REv. 1 (1992); John M.A. DiPippa. Jacob's Blessing: A Review of Shaffer and Cochran's Model of Moral Counseling. 18 U. ARK. LITTLE ROCK L.J. 85 (1995): Sammons, supra note 16; Thomas L. Shaffer \& Rober F. Cochran, Jr.. Lavyers as Strangers and Friends: A Reply to Professor Sammons, 18 U. ARK. LITTLE ROCK L.J. 69 (1995). 
systems and understand their political effects before they can move on to creating new philosophical models. ${ }^{199} \mathrm{He}$ warns that even seemingly apolitical traditional theory can have political effects. ${ }^{200}$ This discussion demonstrates that Gramsci's insight is true of ethics discussions as well. The next generation of ethics scholars must be careful to look back on and deconstruct the traditionai ethics models before they move forward. Otherwise, seemingly innocent naturalized ways of viewing the world will infect their work, and they will find that the problem of client domination persists. The ethical mirror model offers scholars a vivid description of what lawyering might look like if we move beyond ideology-of-domination constructs. This model offers one possible way to affirm client autonomy in lawyering. As scholars identify other ideological constructs in the traditional models, they can create new ethics models that facilitate client autonomy in other ways. ${ }^{201}$ Although the ideology of domination has been a formidable barrier, one that has prevented us from exploring the full range of lawyering possibilities, we have both the tools and the obligation to ensure that it does not become a permanent cognitive barrier.

199. See NEMETH, supra note 170 , at 15 (summarizing Gramsci's views).

200. See id. The political effect of traditional ethics scholarship is that the seemingly innocent directive allowing lawyers to import their moral codes into client representation ends up disempowering persons from groups that are not well represented in the lawyering field.

201. But see Tremblay, supra note 10, at 42 (arguing that any of the activist moral stances suggested to lawyers will tend to interfere with clients' instrumental legal goals). 